\title{
Integrating spatial accessibility in the design of volcano evacuation plans in the French West Indies (Guadeloupe and Martinique)
}

\author{
Frédéric Leone ${ }^{1 *}$, Jean-Christophe Komorowski², Monique Gherardi-Leone ${ }^{1}$ and Guillaume Lalubie ${ }^{3}$
}

\begin{abstract}
This article provides a spatial and comparative approach to evaluate the territorial accessibility in the event of a volcanic crisis in the French West Indies. A spatial assessment of resources and populations exposed to volcanic hazards is performed, followed by an assessment of the risk of territorial isolation due to lahars. Modelling of the risk of terrestrial isolation builds upon graph-based computations and indices that take into account the specific vulnerability of river-crossing structures and the knowledge of historical lahars. Another application of the graphs concerns scenarios for the evacuation of population, the sole efficient response to an eruption. This results in an optimised division of areas to evacuate in order to assess the potential reduction of the load on the road network. These different results are integrated into a prototype for evacuation maps intended for local authorities. The situation of Guadeloupe is of greater concern than that in Martinique, given the level of exposure, the potential losses of accessibility in case of lahars, and the greater and on-going volcanic unrest of La Soufrière volcano in Guadeloupe.
\end{abstract}

Keywords: Volcano, Lahar, Risk, Accessibility, Evacuation, Antilles

\section{Introduction}

The comparative and spatial analysis of the territorial ${ }^{1}$ accessibility developed in this article concerns two active volcanoes in the French West Indies, namely La Soufrière in Guadeloupe and Mount Pelée in Martinique. It focuses on the particular cases of lahars, debris flows of volcanic origin that can occur in the early stages of an eruption and continue well after the eruptive peak (Newhall and Punongbayan 1996; Lavigne et al. 2000; Lavigne and Thouret 2000; Lalubie 2013). Due to their effects of accumulation, impact and erosion, lahars are highly capable of disrupting road networks, notably by destroying bridges (De Bélizal 2013). This can reduce spatial accessibility,

\footnotetext{
${ }^{1}$ Territory as a dynamic spatial system, built and managed by man, lived or perceived, structured around various key assets/resources.
}

\footnotetext{
* Correspondence: frederic.leone@univ-montp3.fr

'Université Paul Valéry Montpellier 3, site de St Charles, Route de Mende,

34199 Montpellier Cedex 5, France

Full list of author information is available at the end of the article
}

especially in small territories with limited territorial resources. Lahars can trigger preventive evacuation and lead to problems in the ability to access resources after the crisis. These difficulties can be anticipated via a territorial risk assessment (Defossez et al. 2017). Such an assessment is required, first to assess the exposure of major resources to the main identified volcanic hazards, and then to model the potential reduction in road accessibility via graphbased computation. The goal of the assessment presented here is to map isolation risk of some portions of the territory and associated resources, and to take these into account in crisis planning, notably in the preventive phase of evacuation of the population. The different results are integrated into a prototype for evacuation maps, in anticipation of the upcoming publication by the authorities of a revised volcano emergency response plan.

\section{Spatial accessibility and emergency management}

In geography, accessibility is the ability to reach places, people and economic activities with more or less ease 
(Bavoux and Chapelon 2014). In the framework of a geographic approach to risk analysis focused on assets, the potential degradation of accessibility by different natural causes is an essential component of territorial vulnerability (D'Ercole and Metzger 2009; Demoraes 2009; D'Ercole et al. 2012; Defossez et al. 2017). This degradation can delay rescue operations, reduce post-crisis resources and isolate populations to be evacuated or rescued. The analysis of degradation in road accessibility poses the problem of interdependency of major land assets and questions the alternative abilities of functioning during a crisis, and thus, of territorial resilience (Dauphiné and Provitolo 2007; Reghezza-Zitt et al. 2012). This last point requires careful attention concerning small, insular, ultra-peripheral, isolated and confined spaces (Komorowski et al. 2016; Brown et al. 2015a). Small islands like Martinique and Guadeloupe are furthermore highly dependent on external resources and on their road networks that are essentially coastal and with low connectivity, and highly exposed to lahar-prone rivers draining radially from the central mountainous areas. By contrast, good road accessibility will promote an efficient preventive evacuation process (Péroche et al. 2014), the support of populations after a disaster (Ukai 1997), and territorial resilience by accelerating a return to a normal situation (D'Ercole et al. 2012; Zaninetti, 2013).

Accessibility can be viewed in the context of three main phases of a volcanic crisis, namely an evacuation phase, a rescue phase and a post-crisis recovery phase although in the early phases of an eruptive crisis, ash emission could also impact the territory and limit accessibility even before an evacuation is called. Depending on the departure or arrival areas (risk, shelter or resource areas), several types of land accessibility can be defined and analysed: (1) between the danger zones and shelter zones during the preventive evacuation phase; (2) between the resource zones and impacted zones in the rescue phase; and (3) between the shelter zones and the resource zones in the post-crisis recovery phase (Leone et al. 2013).

From a methodological point of view, D'Ercole and Metzger (2009) aimed to analyse accessibility as an essential component of territorial vulnerability during crises, but without developing quantitative assessment methods. Other researchers have applied graph theory to model the degradation of accessibility in the face of different natural hazards (Chang 2003; Gleyze 2005; Sohn 2006; Nabaa 2011; Bono and Gutiérrez 2011; Postance et al. 2017). More recently, work on tsunami risk in Mayotte (Leone et al. 2013) and on debris flows and avalanche risk in the French Alps (Leone et al. 2011, 2014a; Utasse et al. 2016), attempted to formalise a territorial approach for assessing indirect risk by suggesting deterministic models (for a given scenario of road interruption) or probabilistic ones (via interruption and isolation risk indexes) of road accessibility loss. Their goals were to anticipate accessibility losses and map them with indicators such as the increased travel times and distances, the probability of being cut off and isolated and the volume of potentially inaccessible assets. However, there are very few studies referring to accessibility problems related to a volcanic crisis, and even more so regarding those that address modelling of accessibility. We can mention the works of Mei et al. (2013) and Jumadi and Quincey (2016) on Merapi volcano (Java, Indonesia), Morin (2012) on Piton de la Fournaise (Réunion, France), d'Alberico et al. (2012) on Phlegraean Fields (Italy) or Pagneux (2015a) on Öræfajökull volcano in Iceland.

Accessibility becomes crucial during preventive evacuation phases related to natural phenomena for which confinement is generally not recommended: tsunamis, landslides or volcanic eruptions. Facing the intensification of an eruption, whose peak can occur several days after the volcano awakens, a massive and anticipated population evacuation appears to be a relatively efficient response to minimise the number of victims (Wilson et al., 2012; Baxter et al. 1998). But it is a complex process that requires a minimum of planning, notably of the zones to evacuate preventively and of the itineraries to follow to reach secured sectors in minimum times and with minimum traffic congestion. Well managed, this process has been proven to be efficient, in particular for the eruptions in 1991 of Pinatubo volcano in the Philippines (Leone and Gaillard 1999), Merapi in Indonesia in 2006 and 2010 (Mei et al. 2013) or more recently in Bali (Mount Agung) (ERCC (Emergency Response Coordination Centre) 2017) and Vanuatu (Manaro Voui) (IFRCa (International Federation of Red Cross and Red Crescent Societies) 2019). The lack of evacuation anticipation resulted in disastrous consequences during the eruption of Mount Pelée in 1902 (Ursulet 1997), of Soufrière Hills on Monserrat in 1997 (Lesales 1999), of Nevado Del Ruiz in 1985 in Columbia (Voight, 1990; Pierson et al. 1990; Thouret 1990) and recently just as tragically during the eruption of Fuego in 2018 in Guatemala (IFRCb (International Federation of Red Cross and Red Crescent Societies) 2019).

\section{Volcanic risk in the West Indies}

The French West Indies have two active volcanoes, Mount Pelée, located in the north of Martinique, and La Soufrière located in the South of Guadeloupe on BasseTerre. These two volcanoes belong to the intra-oceanic subduction arc of the Lesser Antilles that includes 16 active volcanoes (activity during the Holocene) aligned between the islands of Saba in the north and Grenada in the south (Brown et al. 2015b). Among them, nine have experienced activity during historical period (since 1270) (GPV (Global Volcanism Program) 2013). The most 
important activity can be found in the central part of the arc. These volcanoes emit differentiated, viscous magmas with high explosive potential. Three eruptive styles dominate the activity: eruptions with growth of a lava dome, explosive eruptions with an open vent, and superficial phreatic eruptions (Lindsay et al. 2005). Furthermore, these volcanoes are characterised by the recurrence of collapses and partial landslides of their slopes leading to the formation of avalanches of potentially tsunamigenic debris (Komorowski et al. 2005; Boudon et al. 2007; Peruzzetto et al. 2019). An estimated 528,800 people $^{2}$ currently live less than $15 \mathrm{~km}$ away from these 16 volcanoes, a radius that encompasses the most deadly hazards (Fig. 1). This exposure concerns 346,500 people if we consider the nine most dangerous volcanoes with historical activity. The Guadeloupe island holds the record of human exposure (La Soufrière), followed by Dominica (Morne Plat Pays and Morne Watt), then by Saint-Lucia (Qualibou), Martinique (Mount Pelée), Saint-Vincent (Soufriere), Grenada (Kick'em Jenny), Montserrat (Soufriere Hills) and Saba.

There are six known historical eruptive crises for La Soufrière (1690, 1797-98, 1812, 1836-37, 1956, $1976-$ 77) (Komorowski et al. 2005) and four for Mount Pelée (1792, 1851-52, 1902-05, 1929-32) (Boudon et al. 2005; Lesales 2005). These were characterised by phreatic or magmatic eruptions associating all of the main volcanic hazards including small debris avalanches, except lava flows (see section 4 for volcanic hazards). The eruptive crisis of Mount Pelée in 1902-1905 ended with nearly 30,000 victims after eruption peaks with pyroclastic flows on 8th May (29,000 deaths in Saint-Pierre) and 30th August (1000 more deaths in Morne-Rouge) (Ursulet 1997). The event on 8th May remains the deadliest volcanic disaster in the world attributable to a direct volcanic hazard (Siebert et al. 2010). It is also the greatest natural catastrophe recorded on French soil, as measured by the number of deaths. This eruption, whose scientific reconstitution by geologist Alfred Lacroix marked the beginning of modern volcanology, led to the total destruction of the town of Saint Pierre, the economic capital of the island at the time (Lacroix 1904). It strongly influenced the development of Martinique thereafter by relocating most activities in the current capital, Fort-de-France.

La Soufrière in Guadeloupe has not experienced major magmatic eruptions since the island was colonized by the French in 1635 and the last magmatic eruptions in

\footnotetext{
${ }^{2}$ The population data used comes from the 2015 GHSL (Global Human Settlement Layer) world gridded database at $250 \mathrm{~m}$ resolution (https://ghsl.jrc.ec.europa.eu/download.php?ds=pop) (Florczyk et al. 2019). The volcanoes come from the 2013 Global Volcanism Program database (https://volcano.si.edu/list_volcano_holocene.cfm) (GPV (Global Volcanism Program) 2013).
}

1530 (Boudon et al. 2008; Komorowski et al. 2008), although a minor magmatic eruption may have occurred in 1657 (Legendre 2012). The 1976 phreatic eruption, considered as an aborted magmatic eruption (Feuillard et al. 1983; Komorowski et al. 2005; Villemant et al. 2005 and 2014), did however strongly affect the population in Guadeloupe and was the subject of a scientific controversy that highly complicated the crisis management (Lepointe 1984; Feuillard 2011; Hincks et al. 2014). This eruption led to the evacuation of the seven most exposed towns in the south of Basse-Terre and nearly 73,000 people had to find shelter for several months, mainly on Grande-Terre. Unlike Mount Pelée, which has experienced significant decrease in activity since the last eruption in 1932, seismic, fumarolic and thermal activity of La Soufrière has been slowly increasing since 1992 (Komorowski et al. 2005; OVSG-IPGP 1999-2019). This has led the authorities to raise the alert to the "yellow" level ${ }^{3}$ in recent years. Due to the presence of toxic gases, the town of Saint-Claude issued a municipal order forbidding public access to certain areas at the summit; this has been in effect since 2015. These warnings are based on an instrumental surveillance ensured by the two volcanological observatories of the "Institut de physique du globe de Paris" (IPGP). This monitoring is the first step in crisis planning defined by the volcano emergency preparedness plans. These plans describe the different measures that will be implemented as a response to a future potential volcano emergency including massive, preventive evacuation of the population.

\section{Study areas}

The two areas studied are concerned with the extension of volcanic hazards to a distance of $15 \mathrm{~km}$ radius from the summit of either La Soufrière or Mount Pelée. These simplified perimeters have been fixed to encompass the main volcanic phenomena that may occur according to several eruptive scenarios pre-established by IPGP and BRGM scientists (Fig. 2). Each hazard level has been defined by the combination of a probability of occurrence and a potential intensity. The hazards maps rely on geological, geomorphological, stratigraphic and geochronological studies and a reconstitution of the major past eruptions. In Martinique, the hazard map used was produced by the French "Bureau de Recherches Géologiques et Minières" (BRGM) (Stieltjes and Mirgon 1998). It introduces four danger zones (from low to very high) and integrates seven major phenomena for a maximum credible eruption scenario (lava dome, gas, pyroclastic flows,

\footnotetext{
"Yellow level" means: "Overall activity observed to be increasing (variations in some parameters) and possible time frames for a next eruption in year(s) or months" (http://volcano.ipgp.fr/guadeloupe/ Bulletins/last_bulletins.pdf).
} 


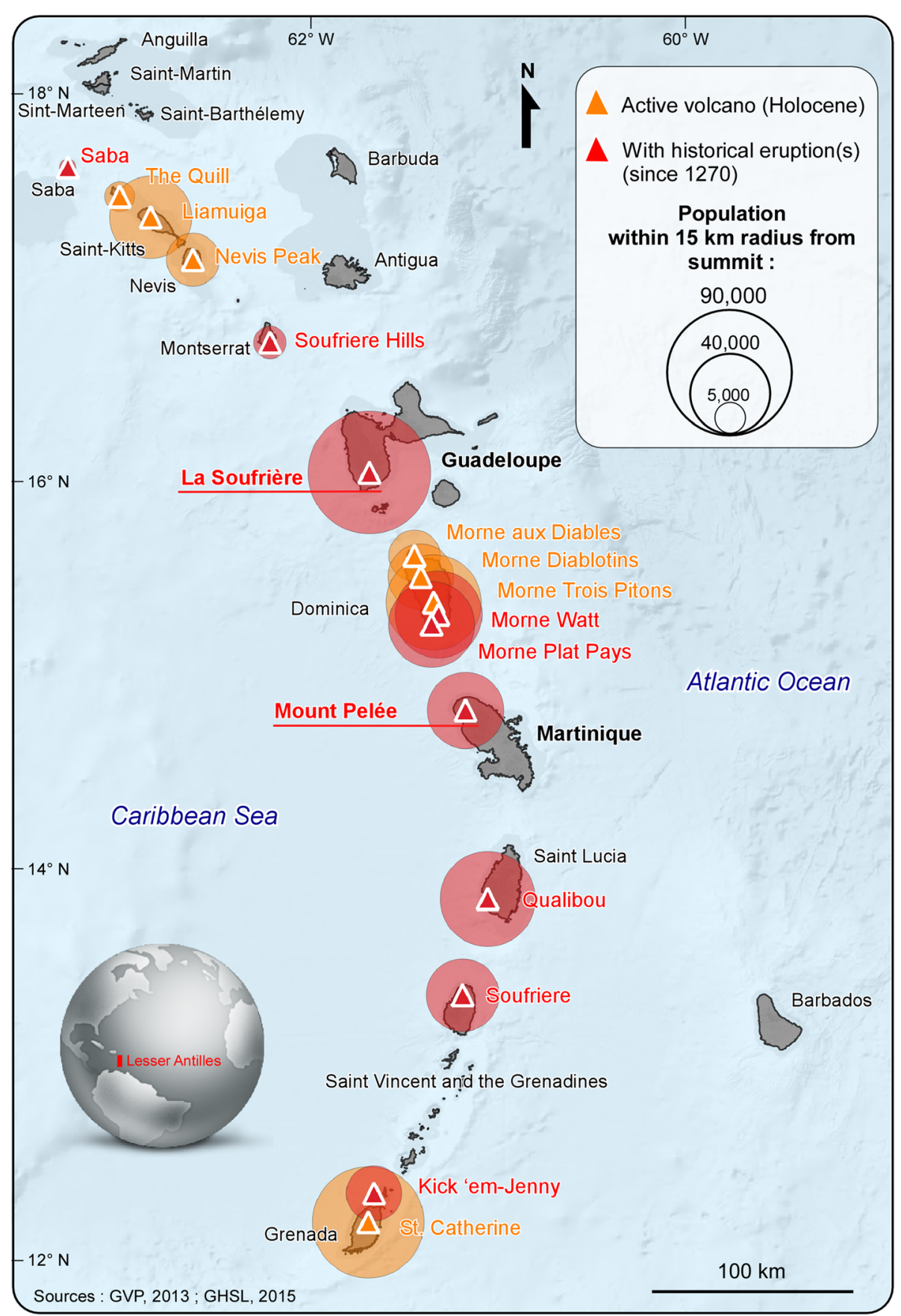

Fig. 1 Active volcanoes of Lesser Antilles and associated population exposure

ash, lahars, tsunamis, landslides). The rest of the territory can however also be impacted by ash fall, but of lesser intensity. The map of volcanic hazards for Guadeloupe was produced by the IPGP (Komorowski et al. 2005) based on the reconstitution of five past eruptive scenarios (over the past 15,000 years). Currently being revised, it introduces five danger zones and the same volcanic phenomena as for Mount Pelée, including seismicity of volcanic origin.
The rest of the territory can also be impacted by volcanic ash fall. These two reference maps of integrated volcanic hazards that we used in our assessment are comparable, although they differ slightly as to the methods of hazard classification. Despite the multiple uncertainties linked to the complexity of volcanic phenomena, these maps describe and warn of risks that could result from future eruptive activity by localising the major exposed assets/ 


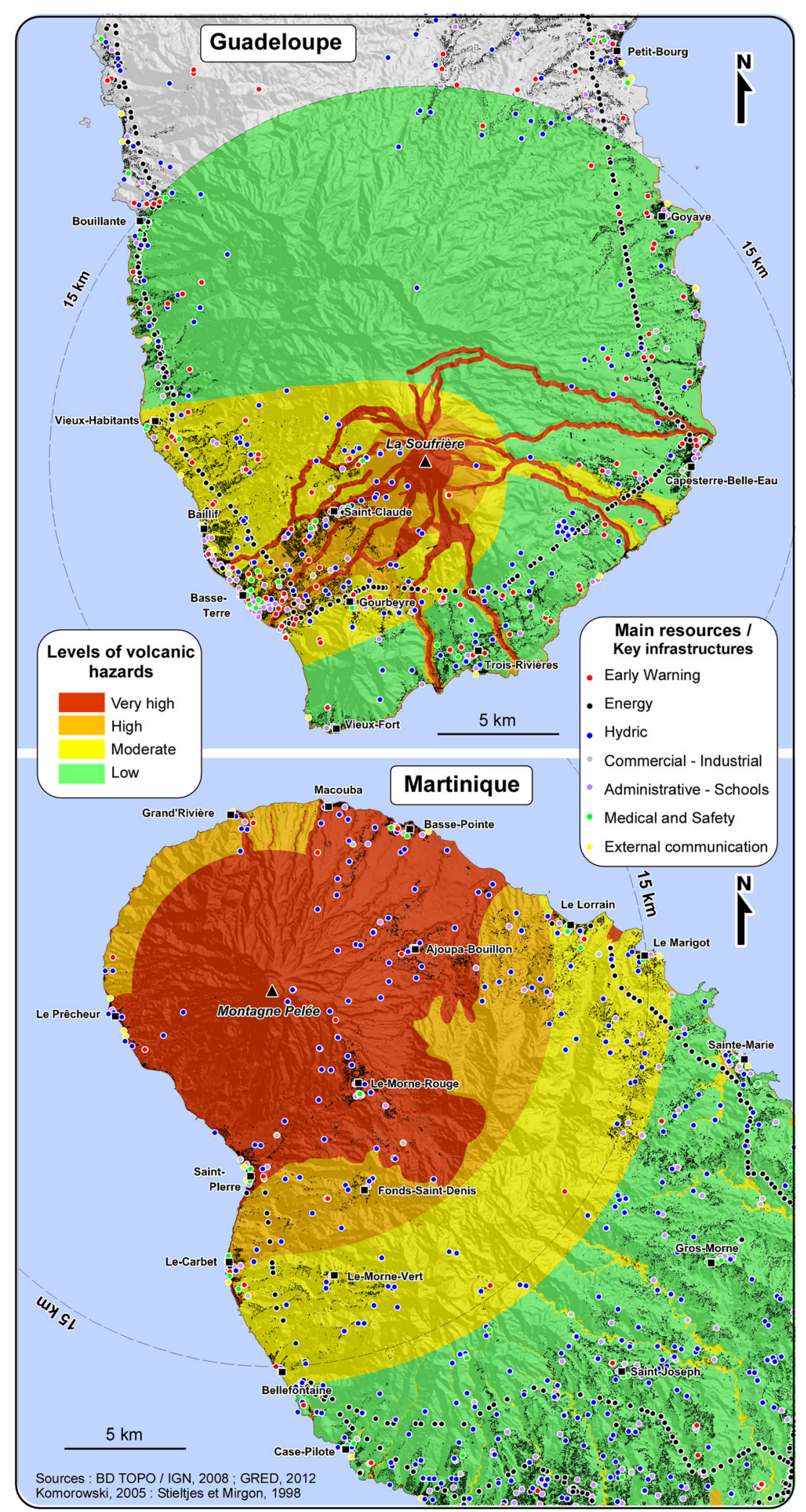

Fig. 2 Areas studied $(R=15 \mathrm{~km})$, levels of volcanic hazards and major/key resources exposed 
resources (infrastructures and population) and the areas that should be evacuated in priority in the event of a crisis.

\section{Assessment of major resources exposed}

An initial assessment of the territorial exposure was established within a hazard perimeter of $15 \mathrm{~km}$ radius by considering the major resources (infrastructures and population), related to the notion of critical infrastructures defined in 2005 by the European Communities Commission (Galland 2010; November 2012). The resulting GIS database organises these infrastructures into seven classes: means of alert, energy, water, commercial and industrial, administration and schools, medical and safety, external communication (ports and airports). This geo-referenced information was collected in the field and cross-checked with preexisting databases (OSM collaborative project, BD TOPO / IGN, Internet). The other group of assets considered is the location of overnight population aggregated on residential buildings. Different exposure studies use overnight population data (Liu et al. 2010; Pagneux 2015b), which are easily compiled from census data on the residential population. The data used here come from the 2010 population census (INSEE), available at the scale of the census block (Guadeloupe) or $200 \mathrm{~m}$ square grids (Martinique). These data were then disaggregated on housing polygons (BD TOPO / IGN) using the "POPEVAL" population density per inhabitable area method (CGDD (Commissariat Général au Développement Durable / Service de l'observation et des statistiques) 2012).

The highest levels of exposed population are concentrated in Guadeloupe due to the proximity of the towns of Saint-Claude and Basse-Terre that are located less than $15 \mathrm{~km}$ away from the summit of La Soufrière (88, 300 people in Guadeloupe versus 35,500 in Martinique). The same applies to global resources (669 units, or implantations, versus 264) and especially water resources (167 units versus 143). This quantification of exposure can be further refined by considering, within a $15 \mathrm{~km}$ radius, the four hazard envelopes for each volcano. In Martinique, the situation is reversed where more assets are located in the very high hazard areas (red) than in Guadeloupe. This is particularly true for the resident population $(18,143$ people versus 4630$)$ or global resources (128 units versus 37). This is due to a much more extensive red hazard zone in Martinique. In relative proportion, $5 \%$ of the total population of Martinique is exposed to a very high level of volcanic hazard whereas the rate is only of $1 \%$ in Guadeloupe. However, should we consider the high hazard area (orange), there are an additional 18,000 people exposed in Guadeloupe from the sectors of Saint-Claude and Basse-Terre, whereas in Martinique the consideration of orange zone only raises human exposure by 5500 people.

\section{An index to map the risk for population}

Measuring risk to which population is exposed (potential injuries or fatalities) can also be established via a synthetic index, which in accordance with the analytical definition of risk (André 2004; Leone et al. 2010), combines a minima a hazard level and a population exposure value. To do so, each variable was translated to an index comprised between 0 and 1 (VHI for Volcanic Hazard Index, PEI for Population Exposure Index). The goal was to rank in a relative way the level of Population Risk Index (PRI) and appreciate its spatial variability in each volcanic zone. The VHI includes four levels $(0.25 ; 0.5 ; 0.75 ; 1)$ corresponding to each class of hazard of increasing importance. The PEI was established for each grid point $200 \times 200 \mathrm{~m}$ in size by dividing the population value (Pop) of each grid by the value of the most densely populated grid (Popmax) of the studied area $(15 \mathrm{~km}$ radius from the volcano's summit), so $\mathrm{PEI}=$ Pop/Popmax. Pop max is 745 people in Guadeloupe and 412 in Martinique.

$$
\text { PRI }(0-1)=V H I * P E I
$$

The grids were then converted into points to generate a continuous interpolation of these values. The maps that were obtained show hotspots of population risk that correspond to the sectors where the highest human densities meet the highest levels of volcanic hazard (Fig. 3). This gives for Guadeloupe, in particular, a maximal loss-of-lives risk cone whose apex is located on La Soufrière and that encompasses the inhabited area of Saint-Claude and BasseTerre. In Martinique, the high population risk sectors reflect population density rather than the spatial variability of the hazard, since the maximal volcanic danger zone covers the major part of the studied territory. These two maps provide a rather fine and synthetic analysis of the sectors with high human loss potential, but also of the various infrastructures at risk. They contribute to making the risk a little more tangible by integrating both the volcanic hazards and the associated exposed human assets.

\section{Specific vulnerability of the road network facing lahars}

Lahars are devastating debris flows consisting of a mixture pyroclastic material, rock debris and water in varying proportion that flow down a volcano, typically in rivers, during and following strong rainfall. They can 


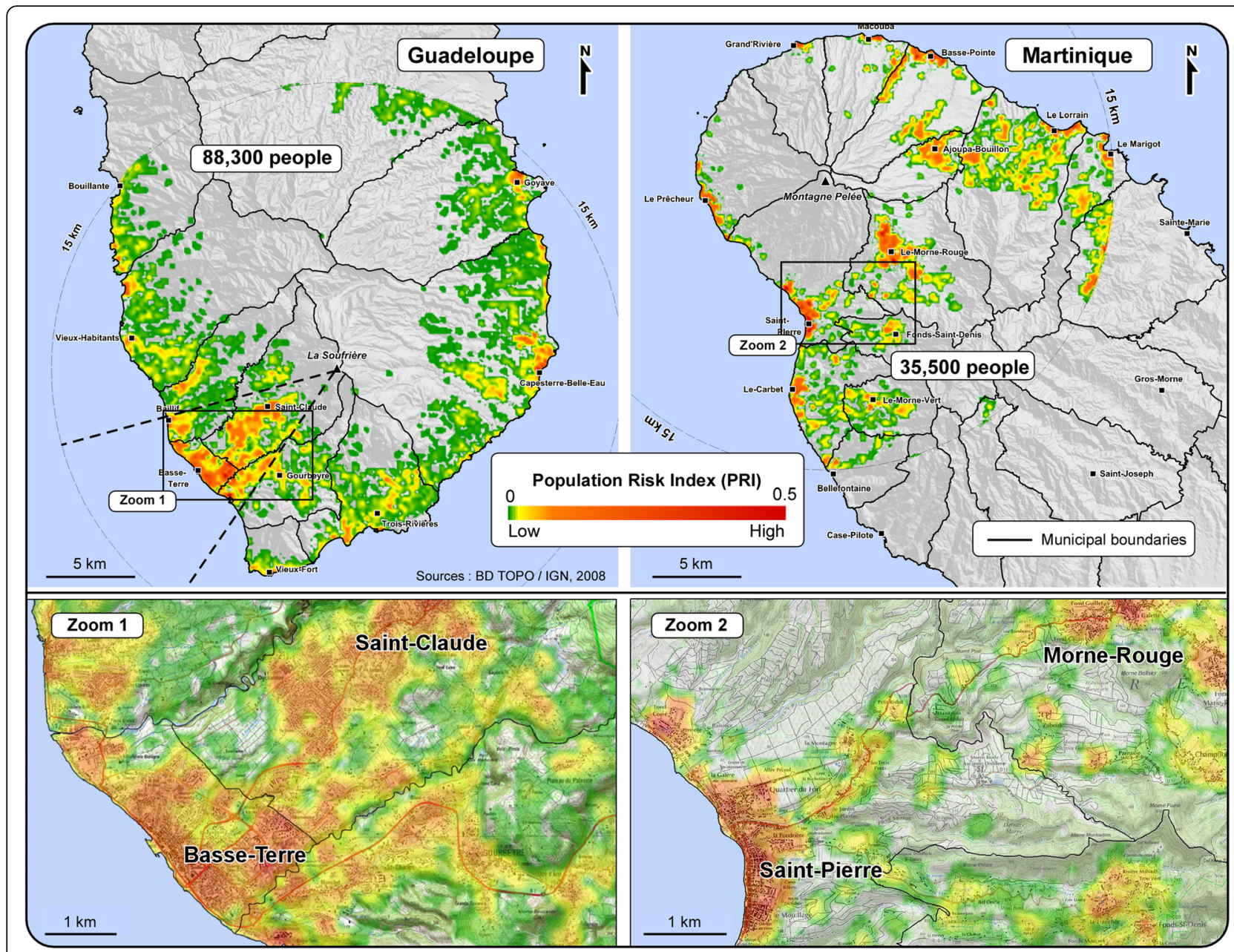

Fig. 3 Interpolated Population Risk Index (PRI), with a zoom on Basse-Terre / Saint-Claude in Guadeloupe, and Saint-Pierre / Morne-Rouge in Martinique

form in the early eruptive stages (syn-eruptive lahars ${ }^{4}$ ). But they can also occur over several years following the end of an eruption (post-eruptive lahars) and unrelated to eruptive activity (non-eruptive lahar) as a result of important rainfall and particularly associated with tropical cyclones. Like other types of debris flows, these phenomena are highly damaging (De Bélizal et al. 2013; Leone et al. 2011; Utasse et al. 2016). They cause significant scouring and erosion, carry large loads of rocks of large size (meters) and broken trees severely impacting

\footnotetext{
${ }^{4}$ In 1902 in Martinique, the first lahar (Rivière Blanche) occurred on May 5, at around 6 a.m., 2 months after the first phreatic explosions and 3 days before the peak of the magmatic eruption. In 1976 in Guadeloupe, the first lahar was triggered on July 8 at around 9 a.m. (Rivière du Carbet) immediately as the result of the first phreatic explosion, when pyroclastic density currents mixed with hydrothermal fluid emitted from the vent, about 1 month before the official massive evacuation of 15 August (Feuillard et al. 1983; Komorowski et al. 2005; Hincks et al. 2014).
}

infrastructure and especially bridges with piles that are particularly vulnerable.

Since the beginning of the fifteenth century, a great number of syn-eruptive, post-eruptive, and non-eruptive lahars have been recorded on the slopes of Mount Pelée (Martinique) and La Soufrière (Guadeloupe). Lalubie (2011 and 2013) reported 165 lahars in his French Antilles Historical Lahar database (BDfahl) compiled for this study, all types considered. At least 39 events can be found in Guadeloupe between the years 1530 and 2009, including 11 primary lahars that impacted the rivers of Galion and Carbet during the eruptive crisis in 1976. In Martinique, between 1605 and 2010, around 126 lahars were reported. This high number can be explained by the major eruptive crises of 1902 and 1929 with 56 lahars for 1902 alone, causing alone the deaths of around 430 people before 8th May (Kennan 1902; Lacroix 1904). Between 1929 and 1932 only 10 lahars were recorded in Martinique. Most of them occurred on the 
same south-west slope, in the course of a river that has now disappeared ("Rivière Sans Nom") and in neighbouring rivers that still exist, Rivière Sèche and Rivière Claire. Also noteworthy is the important number of non-eruptive lahars, notably for the Prêcheur river in Martinique, with 51 lahars that have been reported between 1932 and 2010 including 27 that occurred in 2010 (Lalubie, 2013; Aubaud et al. 2013). Non-eruptive lahars continue to impact the Prêcheur river drainage and the town of Le Prêcheur, particularly since 2018 (OVSM-IPGP 2018; 2009-2019).

Among these historical lahars, at least 13\% submerged roads in Guadeloupe, versus $38 \%$ in Martinique (Fig. 4). In Guadeloupe, the RD 4 (Grand Carbet river, 1976) and RD 11 (Le Galion river, 1976) and a road crossing the Grande Rivière de la Capesterre River (1843) were hit. In Martinique, damage to the coastal road network was mainly due to the lahars of 1902 that impacted the rivers of Prêcheur, des Pères, Sèche, de Basse Pointe, Falaise and Capot, Claire, Blanche (now disappeared), Sans Nom (now disappeared) and Grande Rivière. Out of 56 recorded lahars, 40 led to structures being submerged. But other more occasional events also impacted the road network in Martinique in 1929 (four times), 1970, 1976, 1980 and 2010 (Lalubie 2011, 2013).

According to these historical testimonies, there are no reports of any bridge destroyed, partially or totally, in Guadeloupe, compared to nine in Martinique (1902, 1976, 1980, and 2010). The last lahar that destroyed a bridge in Martinique dates back to 20th June 2010 in the town of Le Prêcheur. This forced the local population to use fishing boats to go from one side of the village to the other whilst it was being repaired. It was destroyed twice beforehand $(1976,1980)$ (Lalubie 2011, 2013; Aubaud et al. 2013).

If the 1902 lahars scenario (Martinique) were to be reproduced in current conditions, this could lead to potential road network disruptions at three fords and six bridges. Without a preventive evacuation, a simultaneous disruption of the network at these nine locations would result in the isolation of $\sim 8000$ inhabitants comprising the towns of Basse-Pointe, Macouba, Grand'Rivière and Prêcheur. As a terrestrial rescue intervention from Fort-de-France, Saint-Pierre, Ajoupa-Bouillon and Lorrain would become impossible. Should the 1929 scenario occur today, it would isolate around 2000 people in the Prêcheur sector. However, the disruption risk of the current network requires a finer analysis of the vulnerability of rivercrossing structures to lahars. This constitutes one of the input data of the following territorial accessibility measurements.

\section{Methods}

\section{Defining the risk of road network cutting}

Each crossing point exposed to a lahar was subjected to a vulnerability assessment aiming to empirically establish, via an index, the risk of being cut. This concerns all the structures included in the circles centered at both volcanoes, $15 \mathrm{~km}$ radius in Guadeloupe and $10 \mathrm{~km}$ in Martinique (Fig. 5). This delimitation took into account the catchment area susceptible of producing lahars. For each of the crossing points assessed (88 in Guadeloupe, 108 in Martinique), we recorded in a GIS database several factors that could affect their physical vulnerability in case of lahars, namely: 1) the nature/type of crossing (masonry bridges, metallic structure, reinforced concrete, fords and aprons, outflow nozzles); 2) the number of central piles for bridges; and 3) the surface of free section under bridge. ${ }^{5}$

The road Cut Risk Index (CRI) proposed is based on an experimental matrix that combines the main interruption factors previously informed. This matrix gives three levels of an Isolation Risk Index (IRI) according to the lahar hazard level threatening the structure, its free section and the presence or not of piles that could further aggravate its vulnerability in case of a lahar (Fig. 6). Structures with important free sections and without piles that can carry away the bridge deck in the event of scouring or impact, are a priori less vulnerable to the interruption risk than the structures with reduced sections such as fords, aprons or nozzles. We allocated, for each structure, the maximum volcanic hazards level characteristic of the catchment area that supplies the waterway that is crossed by the given structure. To do so, we only retained the lahar hazard zones, as defined by the BRGM in Martinique or the IPGP in Guadeloupe, or the "lahar-prone" areas that are impacted by eruptive phenomena that can lead to the formation of lahars such as the area of ash fall deposition and pyroclastic flow emplacement. The envelopes of each of these phenomena are integrated in the overall volcanic hazard maps but remain available individually from the organisations that produce them.

\section{Modelling road accessibility with graphs}

In transportation studies, accessibility can be modelled through the use of graphs and algorithms that simplify networks, measure the time and distance for different itineraries, and facilitate cartographic processes. It is first necessary to convert the network into a graph in the sense of a mathematical object composed of arcs and nodes. The graph must faithfully render the hierarchy of roads and distinguish the types of roads to which different traffic speeds are applied (Appert and Chapelon 2008).

\footnotetext{
${ }^{5}$ The section of space available under a bridge for a lahar to use, in square meters.
} 


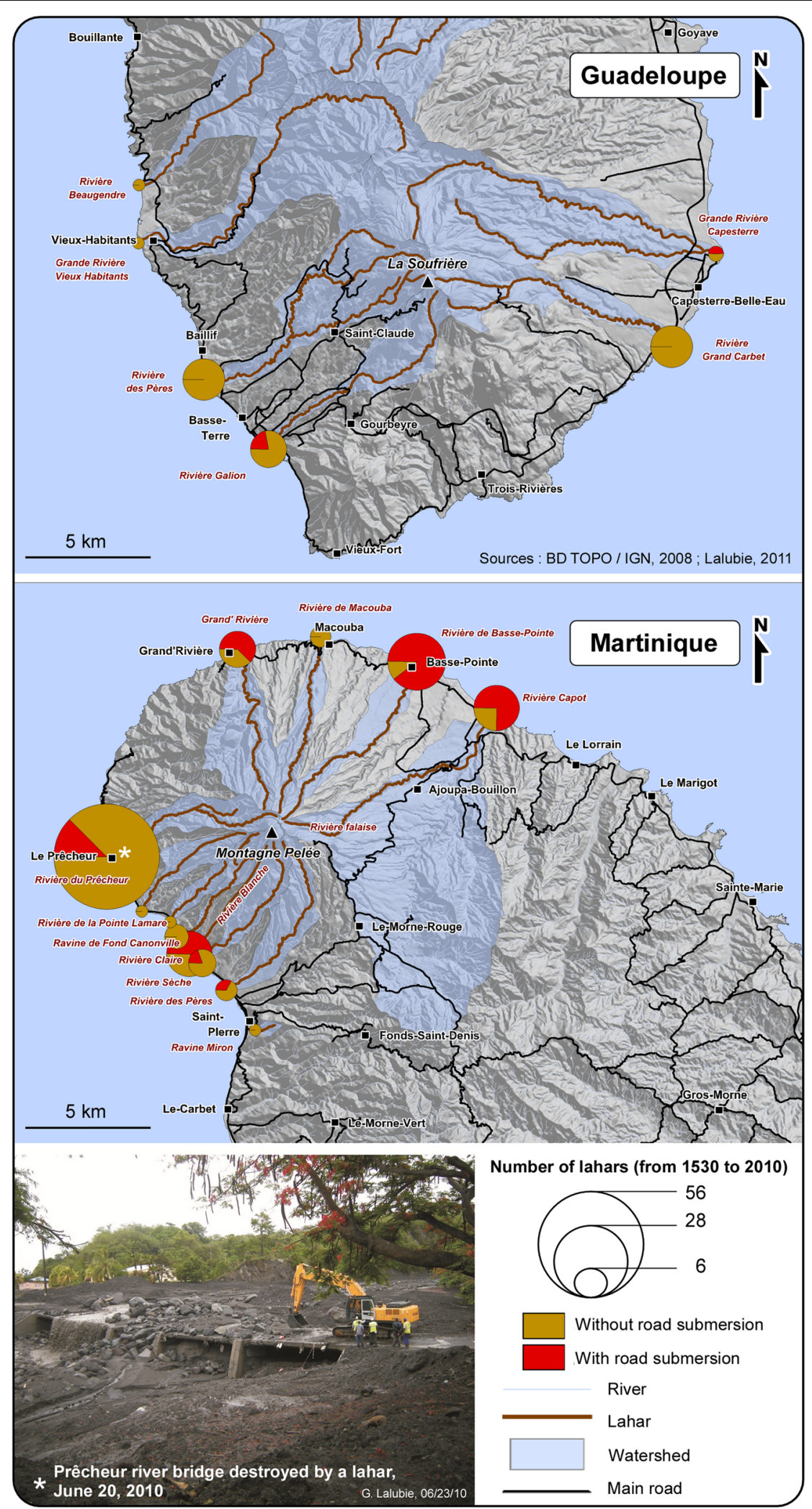

Fig. 4 Historical lahars in Guadeloupe and Martinique, including events that submerged the road network 


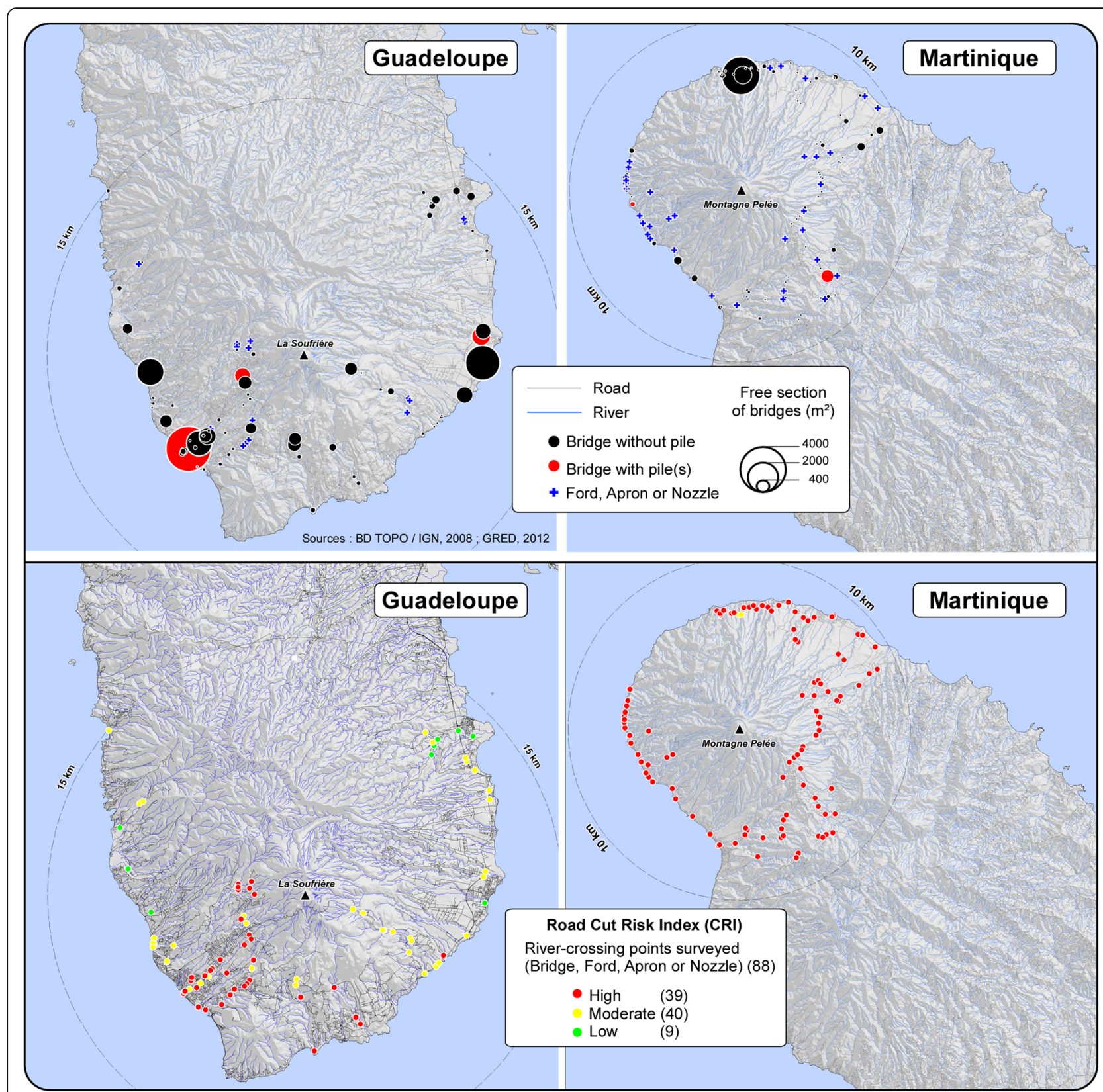

Fig. 5 Vulnerability factors and road Cut Risk Index (CRI) map of river-crossing structures in case of lahars

We computed a road graph from the IGN's database BD TOPO 2009. Accessibility measurements were undertaken with the RouteFinder ${ }^{\circ}$ tool designed to create and use accessibility maps in a GIS environment. The itineraries were defined respectively between each grid point of the territory, accessible under normal circumstances, and several escape points outside of the hazard zone (two in Guadeloupe, three in Martinique) or arrival points for evacuees into the safe zone. These escape points were set $20 \mathrm{~km}$ away from the summit of the volcanoes, in accordance with the authorities, on major routes allowing access to the volcanic zone (N1 and N2 highways in Guadeloupe; N1, N2 and N3 highways in Martinique). We chose to have a radioconcentric starting grid with a maximum $15 \mathrm{~km}$ radius from the summit of both volcanoes. This perimeter includes high to very high level hazard zones, and thus corresponds to a priority evacuation zone in the event of a volcanic crisis. The advantage of a radioconcentric grid is that it provides a cartographic vision centered on the volcano, and thus on the source of danger. Furthermore, it facilitates the spatial division and communication of such division in case of planned evacuation, by specifying the areas to evacuate on the basis of both a direction 


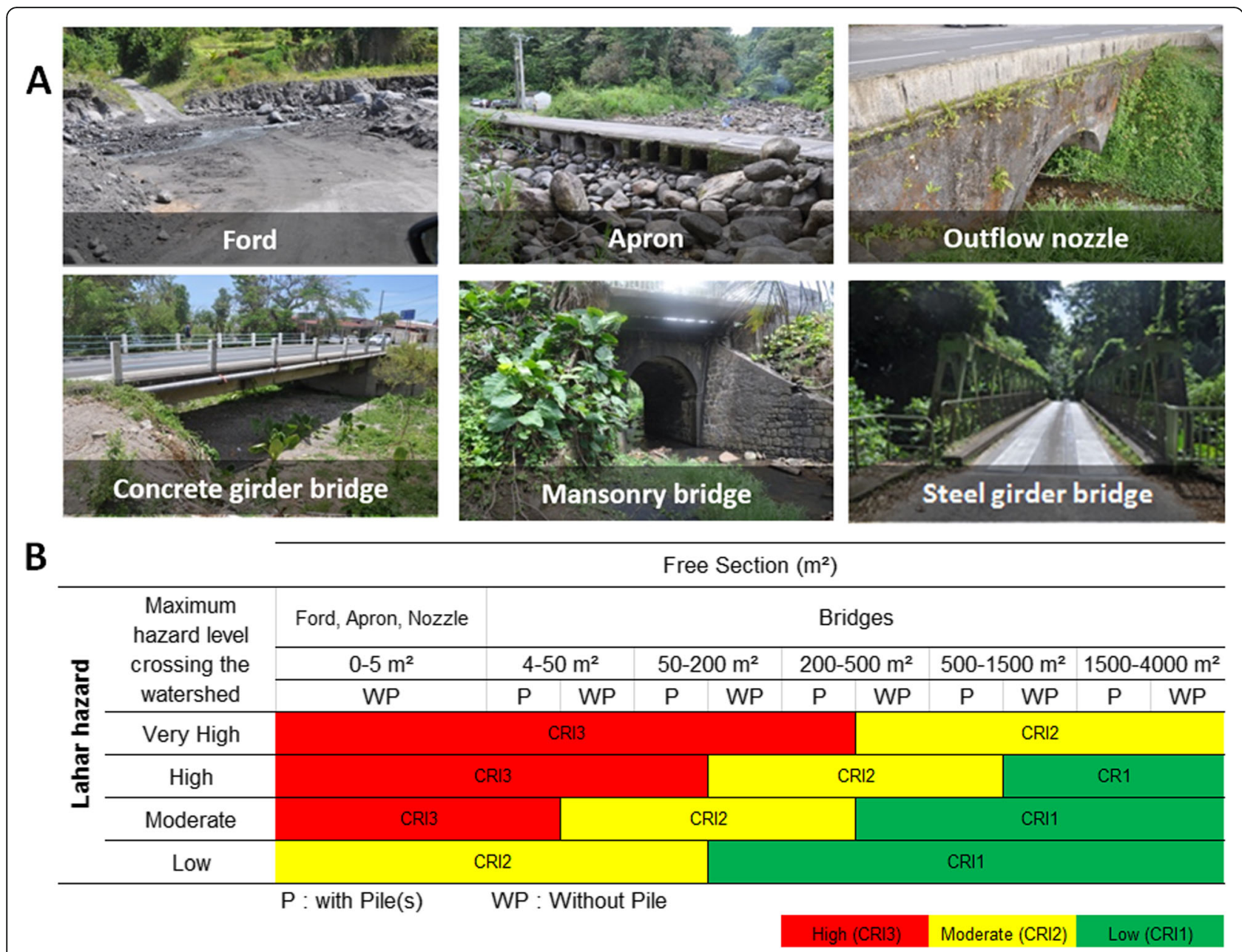

Fig. 6 Road Cut Risk Index (CRI) matrix for river-crossing structures in case of lahars

(angular sectors) and a distance (radius) at the summit of the volcano.

The itineraries, extracted in the form of polylines, were generated in the GIS according to the fastest routes given by Dijkstra's algorithm (Dijkstra 1959), ${ }^{6}$ considering the hypothesis of an evacuation by car, in clear road traffic conditions. The speeds applied are based on the official speed limits applicable in France. The speeds were attributed to the portions of road occurred in accordance with the importance of the section and also its nature, but also in consideration of the local traffic conditions. As a result of tests carried out in the field, the official speeds were lowered by $50 \%$, to keep only five speed classes that range from 5 to $65 \mathrm{~km} / \mathrm{h}$ and respect the hierarchy of the road network on both islands.

\footnotetext{
${ }^{6}$ In graph theory, Dijkstra's algorithm allows to determine the shortest path (in time or distance) to get from one point to another. We suppose here that this is the route followed by a majority of the population.
}

Accessibility measurements were applied using two approaches. The first one concerns the degradation of the territory's accessibility in case of lahars. It anticipates a situation that can occur from the beginning of a volcanic crisis and can compromise the preventive evacuation of population, who become isolated unable to reach shelter zones or to be reached by rescue teams via the road network. It is important to consider that this potential loss of control of the territory can remain long after an eruption and disturb the maintenance of vital infrastructures such as drinking-water supply stations, electric power plants or radiocommunication emitters. Instead of suggesting random scenarios of road disruptions, we chose an empirical method of isolation risk index (IRI) calculators adapted from previous work carried out in the Alps for avalanches (Leone et al. 2014a). To do so, we applied to each selected element of the territorial grid the average of previous Cut Risks Indexes (CRI) obtained at the start of each escape point (2 in Guadeloupe, 3 in Martinique). Each IRI was computed 
from the weighted sum of the CRI of different crossing points on the fastest itinerary connecting this grid element to its escape and safe point, according to the following formula:

$$
\operatorname{IRI}(0-1)=(N b C R 1+N b C R I 2 * 2+N b C R I 3 * 3) / \operatorname{IRImax}
$$

Thus, the routes with the more crossing points with high risk of being cut by lahars present the higher probability of interruption and thus, the higher probability of isolation from the connected grid. The IRI were defined between 0 and 1 by dividing the maximum value (IRImax of each island) and their cartographic processing is obtained by discretisation according to five classes of values. These maps thus classify portions of land that can become potentially isolated, partially or totally, in case of lahars. We stress, that it is the spatial variability of this indirect risk that is important. Indeed, it is fundamental to have the ability to quantify the territorial control loss that these phenomena can lead to by impacting certain assets, particularly those liked to vital resources whose access and maintenance remain essential conditions of efficient post-crisis response.

The second application of graph-based accessibility modelling deals with the preventive evacuation phase. It optimises the division of areas to evacuate on the basis of theoretic travel times between hazard and shelter zones. It also models the reduction in the accumulated net traffic load of the road network that results from a division that is intended to guarantee increased fluidity in the event of planned and directed evacuation.

With the available resident population data for each starting grid element, we can measure and map the accumulated load of passages, in number of people, on the routes connecting these grid elements to escape points. The first simulation considers a single escape and safe point (Pointe-à-Pitre in Guadeloupe, Fort-de-France in Martinique) and presents a saturation of the main roads, particularly in the danger zone. It simulates a potential spontaneous / unplanned evacuation with people taking the usual, fastest routes to reach the capital. The second simulation relied on imposed itineraries (directed), as a result of planning and effective operational implementation by the authorities, towards different pre-defined escape points. This alternative distributes the accumulated loads on the network more evenly and so reduces, at least in theory, the potential traffic jams in particular around the hazard zone.

The review of these results will lead to an optimized prototype of "volcano" evacuation map that integrates the results of population risk indexes found previously. This innovative map will adopt a style guide borrowed from tsunami evacuation plans recently approved by French authorities in charge of crisis management in the French West Indies (Leone et al. 2014b; Girres et al. 2018).

\section{Results \\ Mapping territorial isolation risk in case of lahars}

In Guadeloupe, the sectors most threatened by road closure (IRI >0.8) are the Matouba-Papaye and Dugommier districts in Saint-Claude, the Houëlmont hill where the volcanological and seismological observatory of Guadeloupe (IPGP) can be found, in Gourbeyre, the sector of Zimbimbe plateau towards the second Carbet fall on the heights of Capesterre-Belle-Eau and an entire sector close to the coast between the towns of TroisRivières and Bananier. In Martinique, the town of Grand'Rivière, located at the end of the road network on the north Atlantic maritime side, presents the highest isolation risk, just like its north Caribbean opposite side town, Prêcheur in the Anse Céron (Fig. 7).

Results indicate that Guadeloupe contains, in relative value, the highest number of "isolation-prone" assets, particularly those associated to water-supply facilities (catchment, treatment, processing station, reservoirs). The situation is of lesser concern in Martinique. Coupling these results with those concerning a direct risk exposure, we identify that a high number of assets are subjected both to the risks of territorial isolation and to those of volcanic impact. These areas constitute clusters at high-risk, notably concerning human risk, that may experience difficulties to evacuate in case of lahars. Thus, it would be advisable to plan the evacuation of the population in these high isolation-prone risk areas as a priority before the main road accesses are blocked. We were able to optimise these evacuations by suggesting an adapted division of the hazard area that also guaranteed a good distribution of traffic load on the road network.

\section{Optimising accessibility during the evacuation phase}

Hazard areas to evacuate correspond each to a $15 \mathrm{~km}$ radius hazard circle from the summit of the volcano. In Guadeloupe, this covers all of the towns evacuated in 1976. The graphs and algorithms we derived will assign to each grid element of the hazard area the theoretical fastest travel time to the escape/safe point that is an entry in the closest shelter and safe zone. One can divide the hazard areas into designated evacuation zones and add the corresponding total population. Two zones are suggested for Guadeloupe and three areas for Martinique, each associated to an escape/safe point, and thus to a major road used to leave the hazard zone in a minimum amount of time (Fig. 8). According to our hypotheses, the average evacuation times are of $102 \mathrm{~min}$ in Guadeloupe and $80 \mathrm{~min}$ in Martinique. This does not consider either the network's congestion effects, or the population's reaction time between the moment when 


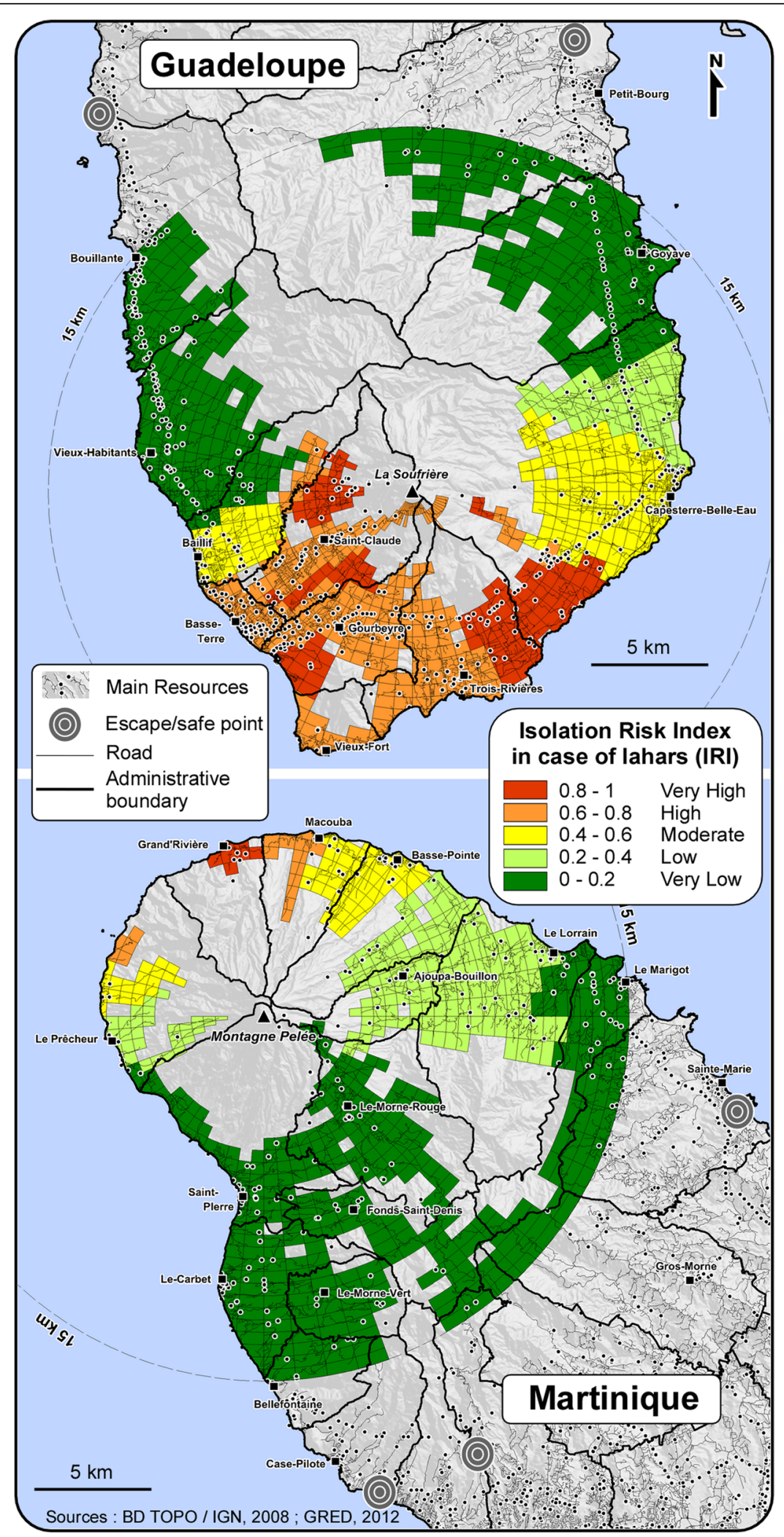

Fig. 7 Territorial Isolation Risk Index (IRI) and key resources threatened by a loss of road accessibility 


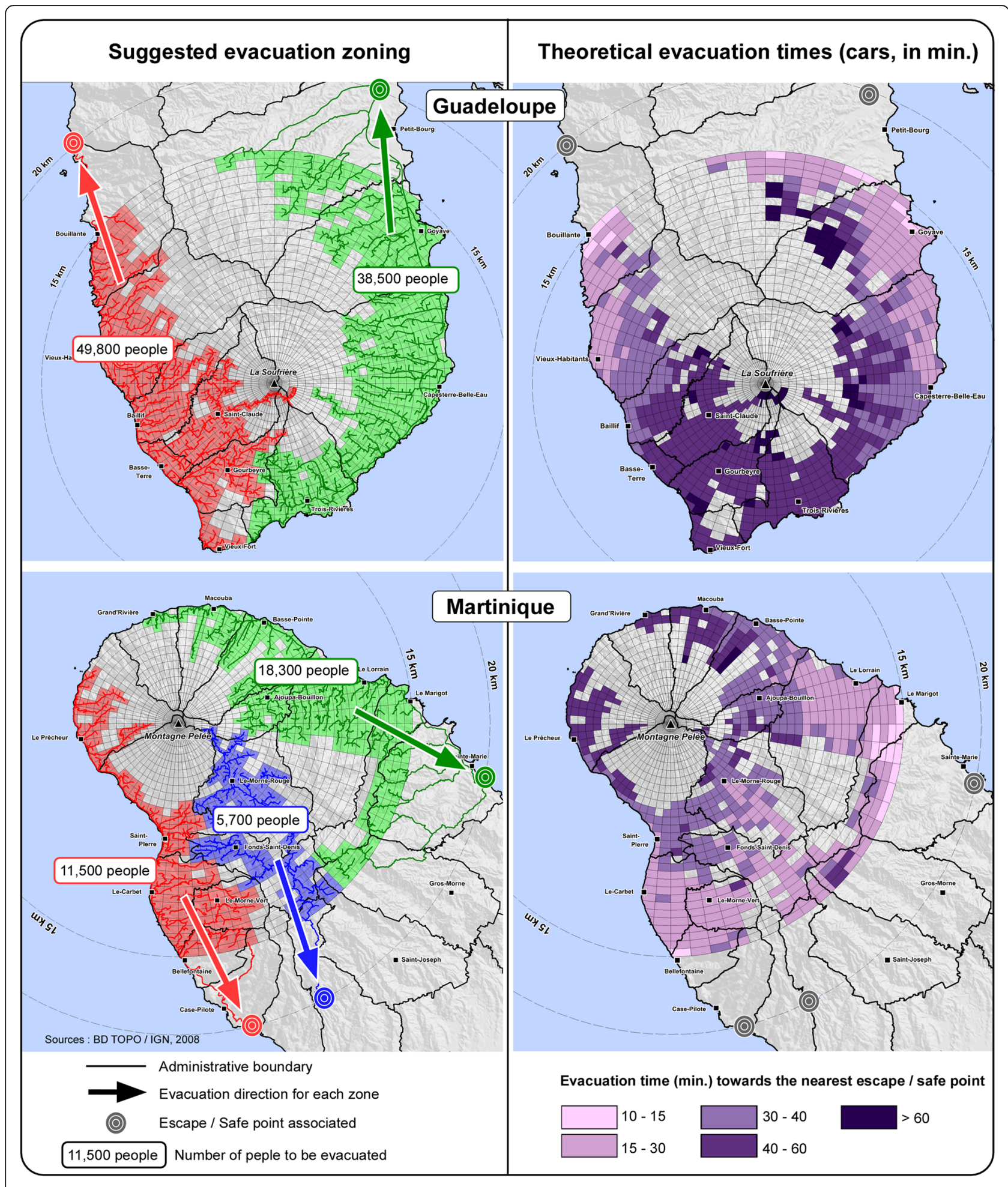

Fig. 8 Suggested optimised division of zones to evacuate and theoretical evacuation times (in minutes) towards the closest escape/safe point

the official evacuation signal is given and the moment when the first departures occur. Nevertheless it is interesting for planning to have the ability to predefine sectors that are particularly distant and isolation-prone from shelter safe areas and to determine their associated exposed population volumes.

This division assigns the accumulated traffic load onto the network on the two coastal roads in Guadeloupe and 
Martinique, while offering an intermediary possibility in Martinique via the central road, known as la Trace (highway N3) (Fig. 9). The prior construction of this new highway would have met the evacuation needs that surged during the evacuation necessary following the 1929-1932 eruption. Work started on the first segment, linking Morne-Rouge to Deux-Choux, in 1929 over a $6 \mathrm{~km}$ portion first, then $8 \mathrm{~km}$, and was finished in 1939 (Lesales 2005).

\section{Discussion: contributing to evacuation planning}

Notwithstanding the significant uncertainties that characterize the anticipation of the nature, style and evolution of a future eruption, this study shows that it is not necessary to possess all the knowledge about the hazard to carry out volcanic risk analysis and suggest strategies to respond the crisis. The maps produced highlight the places that are both strategic and vulnerable, a crucial

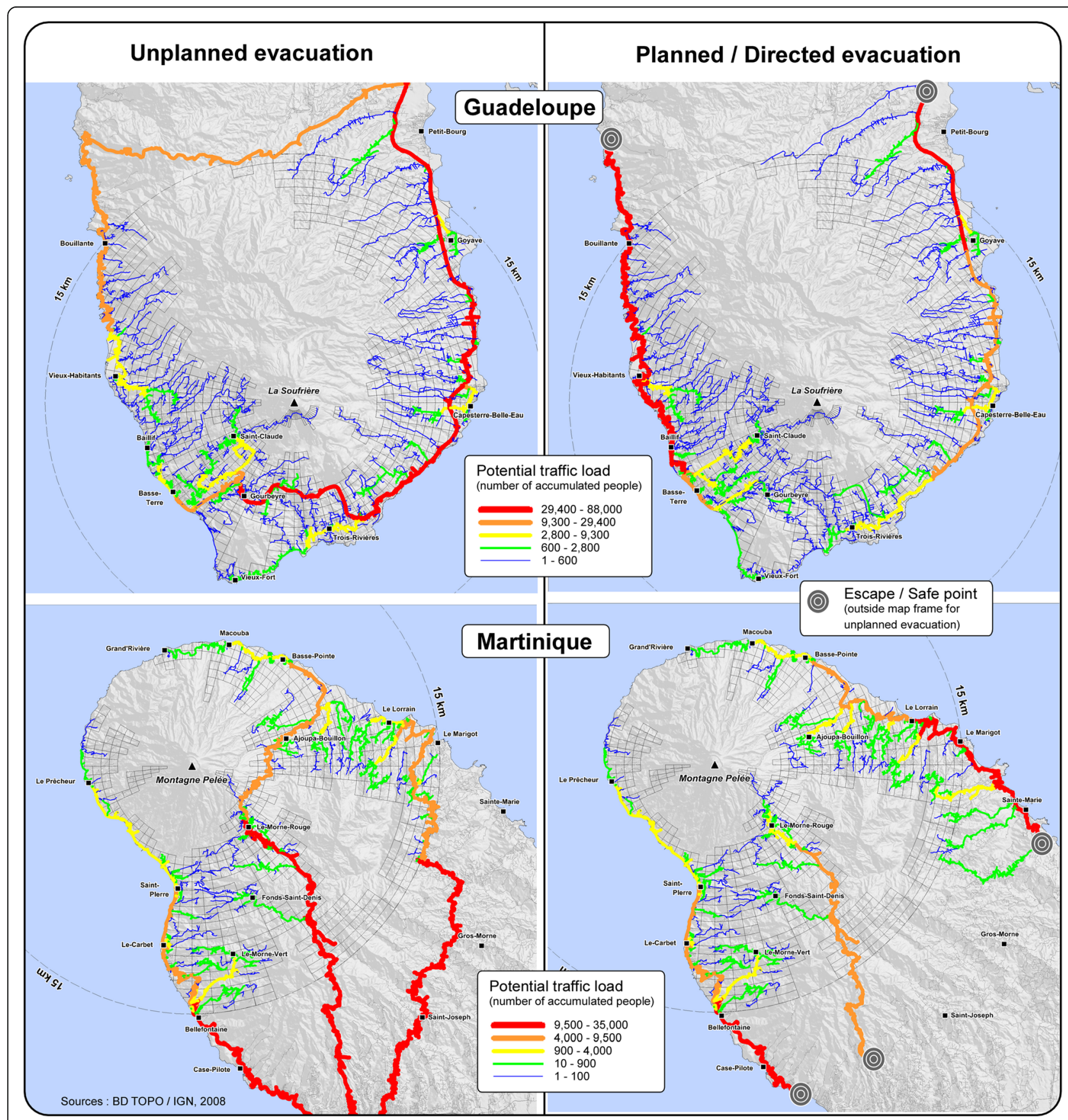

Fig. 9 Theoretical accumulated traffic load on the road network (in number of people) for unplanned (1 escape/safe point) or planned evacuations (with several escape/safe points) 
knowledge for all risk prevention policies (D'Ercole and Metzger 2009).

The risk assessment that was achieved can be refined in the future by taking into account the evolution of assets, their specific susceptibility to damage, the associated economic, human or functional losses, to further improve volcanic hazard maps and eruptive scenarios. The assessment of risks faced by the population and the determination of the indices of accessibility loss show the spatial variability of the risk, both direct (exposure) and indirect (isolation), thus providing fundamental insights for anticipating a crisis and the required response strategies. These indices remain experimental and prospective. Their strength can be discussed at this point, but our empirical knowledge of the field reinforces the legitimacy of certain choices and results. Our methods must be consolidated by a comparison with future work as well as an empirical validation during future volcanic crises by means of postcrisis feedback and the return on operating experience (REX). The scientific improvements of these indices will take into consideration population mobility and its integration in seasonal exposure maps (Wood and Soulard 2009; Pagneux 2015b), road interruption risk indices that integrate models of lahars propagation, the definition of evacuation itineraries that couple modelling and potential behaviours resulting from sociological field investigations, multi-agent evacuation models simulating travel times and possible congestion of the network (Lämmel et al. 2010; Handford and Rogers 2012; Sahal et al. 2013).

Authorities have not integrated in future crisis response strategies the full extent of the 1976 crisis in Guadeloupe, nor the possible consequences of a future magmatic eruption in a zone where urbanisation has practically doubled since 1955 in a $15 \mathrm{~km}$ radius. In contrast, urbanisation in the volcanic hazard zone only progressed by half in Martinique. The major issue concerns water resources given that $\sim 62 \%$ of the daily drinking water production is at risk of being contaminated with the first ashfall event in the initial phreatic no-magmatic stages of any future eruption (versus $28 \%$ in Martinique). Denial of the volcanic risk in Guadeloupe is continuing: we have listed 28 urban planning projects in Guadeloupe (against 14 in Martinique) for the years to come (Sedano 2013). This can be explained by the fact that La Soufrière in Guadeloupe has not experienced a major magmatic eruption since 1530 (Komorowski et al. 2005, 2008) but only non-magmatic eruptions since 1657, unlike Mount Pelée whose 1902 catastrophe has made a lasting impact on the collective memory and thus on the territorial post-crisis recovery. The lack, in Basse-Terre in Guadeloupe, of an adequate urban planning policy that takes into account volcanic risk is in part due to absence of consideration of volcanic hazards into regulatory urban planning and land management documents such as $P P R n$ (natural risk prevention plans). In contrast, Martinique that has adopted, since
2004, a multirisk PPRn that integrates major volcanic hazard zones, within which new urbanisation projects are forbidden (Lesales and Leone 2011; http://www.pprn972.com/). Furthermore, centennial volcanic hazards such as nonmagmatic phreatic eruptions (that can produce a great variety of hazards such as ashfall, ballistic showers, gas emanations, felt earthquake swarms, directed explosions, pyroclastic density currents, landslides, lahars) that in Guadeloupe have a priori probability of at least $1.6 \%$ of occurring in any year (base rate of 6 events in the last 384 years) are not considered in such regulation documents as are the hazards of centennial flooding in the French territory.

Admittedly, volcanological monitoring networks will detect a significant reactivation of the volcano and provide scientific information to shed light on the required public safety decisions needed to anticipate optimally the moment of a massive evacuation of the population. However, the uncertainty about the dynamic behaviour of volcanic systems and their hazardous processes must be taken into account in the decision process. Without delay, existing emergency preparedness plans must be updated to integrate itineraries that may quickly be blocked by the first lahars and/or saturated by spontaneous unplanned evacuations. For example, it can be estimated that the recent lahars of the Prêcheur River in Martinique took about 15 minutes to reach the coastal road after six kilometers of travel. Furthermore, several sociological surveys on human perception and volcanic risks undertaken in Guadeloupe and Martinique over the last two decades have shown that a majority of the population questioned would leave exposed areas, in a spontaneous manner, as soon as the first signs of an eruption were perceived (D'Ercole and Rançon 1994; Leone and Lesales 2009; Mas 2012; Chenet et al. 2014). This is precisely what happened in Guadeloupe on 8th July 1976 at 8:55 am during the first phreatic explosion of La Soufrière, which plunged Saint-Claude into darkness for 20 minutes due to the ashfall (Feuillard et al. 1983; Feuillard 2011; Hincks et al. 2014). The population panicked and spontaneously left the area while the first lahar occurred in the Grand Carbet River. The authorities set up traffic regulations and around 20,000 to 25, 000 people left Basse-Terre for Grand-Terre between 9 and $11 \mathrm{am}$. On the following 9th August, after a strong phreatic explosion with associated ashfall, people in Matouba and Papaye again spontaneously evacuate their homes in the evening to take shelter in welcome centres in Saint-Claude and Basse-Terre.

Given these conditions and considering the experiences in 1976 in Guadeloupe, spatial planning of an evacuation under different scenarios is a priority. The

\footnotetext{
${ }^{7}$ A timeline of the crisis can be found in Hincks et al. (2014) and in: http://www.ipgp.jussieu.fr/ beaudu/soufriere/forum76.html.
} 
population must be informed as of today of the best routes to follow to guarantee their safety with a minimum of confusion (Morin 2012). The prototype of evacuation maps proposed in this study constitutes the first attempts to respond to this need by integrating different results of the current work (Fig. 10). These maps integrate the concept of an optimised division of sectors that need to be evacuated (evacuation basins) and the evacuation roads required for the evacuation. These maps also propose a temporal tri-phasing of the areas required to evacuate on the basis of a combination of population (PRI) and isolation risk indices (IRI). The maps also account for priority evacuation needs for areas with the most people at risk (high densities in sectors with high hazards) and that are prone to isolation and the impossibility to evacuate in case of lahars.
The "La Soufrière volcano" and "Montagne Pelée volcanic eruption" Emergency Preparedness Plans (Plan Orsec in French) currently in use date back to 1999 and 2002 respectively although a revised version of the plan for La Soufrière has just been published by the authorities in January 2019 (Préfecture de la Région Guadeloupe 2019) since our work was completed and submitted to publication. The volcano emergency response plan for Guadeloupe includes a map defining the "spontaneous" or "concerted" evacuation regulation points following two main itineraries to reach Grande-Terre via the "windward" coastal road (east) or the "leeward" coastal road (west) (Préfecture de la Région Guadeloupe 1999). Indeed, the destinations differ from the plan proposed in this article, result in sending more people on the east coast, notably from the towns of Saint-Claude, Gourbeyre and Vieux-

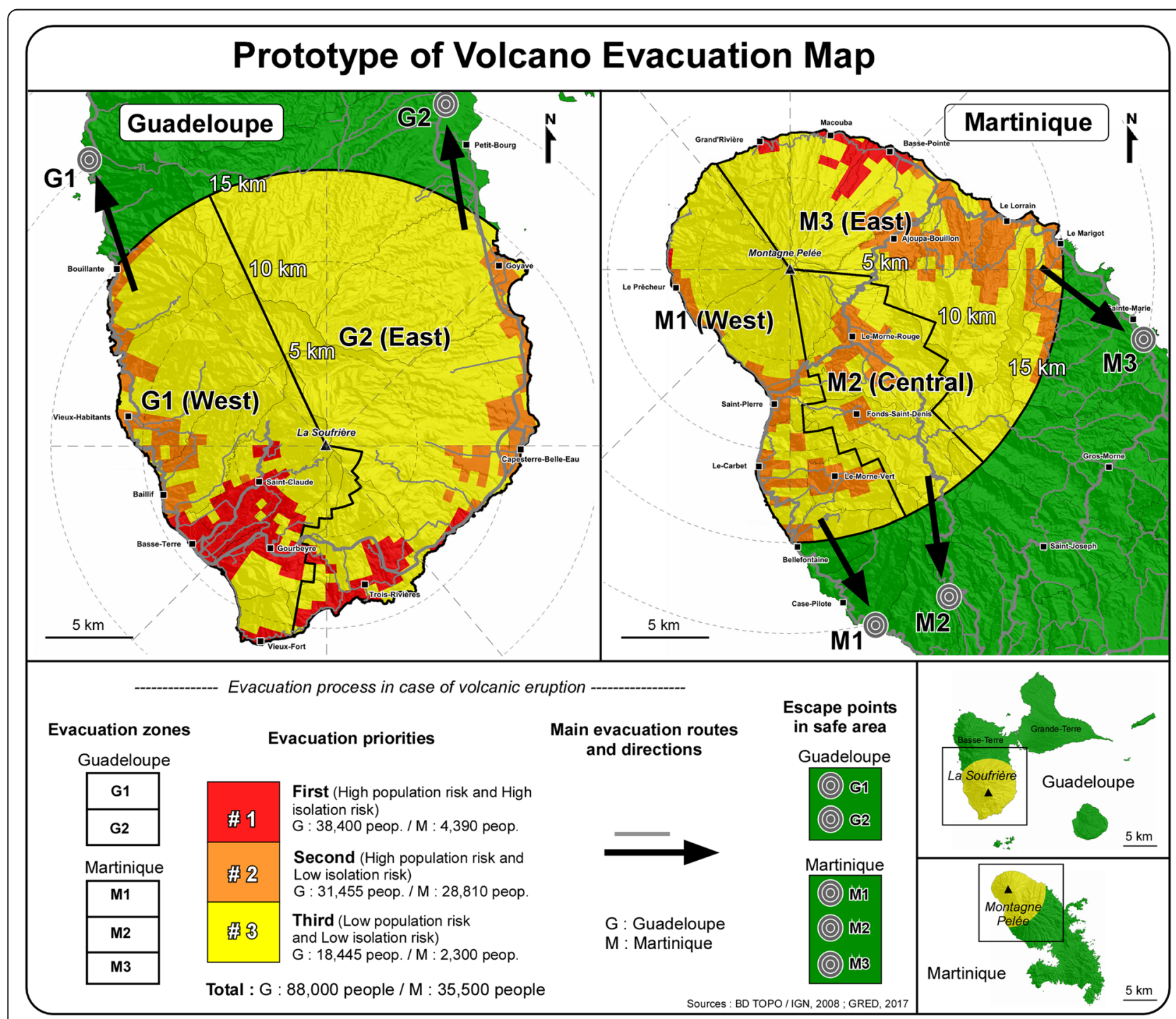

Fig. 10 Prototype of evacuation maps for the management of volcanic crises in the French West Indies (Guadeloupe and Martinique) 
Fort, with the risk of overloading faster the traffic on the road network. The 1999 plan specifies that "evacuations can occur in optimal or degraded volcanic conditions, in this case, one must expect ashfalls with risks of mudslides on the slopes heading towards the sea". It is completed by an evacuation by sea, leaving from Basse-Terre for Pointeà-Pitre harbour. This last option is reserved for the patients from hospitals and clinics in the area. This is a possibility which we have not included, but that remains entirely compatible with our suggestion. In addition, the map accompanying this official plan is very rudimentary, especially in terms of the division of areas to evacuate and the semiology. The new entirely revised version (Préfecture de la Région Guadeloupe 2019) has improved the mapping and the symbology but the strategies remain the same. However, some interesting new knowledge on people's perception of what route they would should they self-evacuate that resulted from sociological analysis in the (CASAVA 2009-2015) project have been included in the new version of the response plan and its associated strategies.

In Martinique, the 2002 volcano PSS provides, in a much richer and higher quality cartography, four planned evacuation scenarios according to the level of threat, and six scenarios of evacuation modes (land and/or sea) established "according to the urgency of the situation (possibility or not of using transit zones)" (Préfecture de la Région Martinique 2002). The proposed evacuation routes respect our suggestions in terms of what number of evacuees and where they can be placed on each itinerary for the different evacuation scenarios. A map also specifies the risks of road interruption linked to the different volcanic phenomena, such as lahars notably. But in our opinion, the plan could be simplified by reducing the number of evacuation scenarios, especially those involving the sea.

Indeed, the multiplication of evacuation scenarios and the very idea that the dividing line between the hazard and the shelter areas is modular over time and depends on the evolution of an eruption that is difficult to forecast with precision, may strongly confuse the population. This spatial uncertainty could well be added within the evacuation perimeter to a more rigid division from the start, such as to avoid what occurred on the neighbouring island of Montserrat in 1997. Indeed, throughout 1996, the complex division of areas to evacuate was refined to allow more flexible management of the small insular space $\left(104 \mathrm{~km}^{2}\right)$. The new map identified seven areas according to the level of activity of the volcano, the status of each area depending on precise eruptive events associated with the activity level and the associated risks (Wilkinson, 2015). As eruptive activity worsened, volcanologists successively adapted the different areas, in February and in June 1997. The last established volcanic risk map had underestimated the potential evolution of the crisis as shown by the events on 25 th June
1997. Indeed, on that day, massive mobile pyroclastic surges reached the maximum limit of the exclusion zone (zones A and B) to the North while at the same time generating a small secondary flow that moved west outside zone $\mathrm{B}$ of the evacuation zone for about $1-1.5 \mathrm{~km}$ and into zone $\mathrm{C}$ (access limited to short visits by workers and residents with rapid means of exit) but that fortunately remaining well-channelled in the deep Belham river (Loughlin et al. 2002). Occurring in the middle of the day, around 1 o'clock, this sudden increase in the intensity of pyroclastic flow activity surprised about 80 people that had remained in the exclusion zones $\mathrm{A}$ and $\mathrm{B}$ of the risk map, a few die-hards who had refused to evacuate, but also working farmers, and owners simply visiting their locality who also refused to abide to the evacuation orders and the exclusion zonation. The June 25th pyroclastic caused the deaths of 19 people (Loughlin et al. 2002). Based on their own appraisal of several months of activity without any major change, the victims probably did not take into account the recent increase of the eruptive activity and the reclassification of the localities into full "No access" exclusion zones A and B. This led authorities to review both the adopted zoning and the alert system to produce a new risk map. The latter was much more restrictive, classifying the entire south of Montserrat as an "exclusion area". In September 1997, as explosions grew more numerous and violent, the exclusion area was extended to the north, thus reducing the safe area. During the activity between August and December 1997, the capital Plymouth, and the only airport of the island were entirely destroyed (Lesales 1999; Loughlin et al. 2002; Sparks et al. 2002).

\section{Conclusion}

An assessment of territorial risks is an indispensable prerequisite for the elaboration ad implementation of a preparation strategy and the reinforcement of response capacities facing volcanic crises. We must establish and update the latest knowledge about hazards, data on the exposure of human and strategic assets, specific vulnerability analyses, and undertake quantitative assessments of the loss of territorial accessibility due to hazards. This study sheds light on part of the volcanic diagnosis on two particularly vulnerable French territories, Guadeloupe and Martinique. The results converge towards the elaboration of methodological tools and strategies that can provide valuable insights into the operational design of population evacuation plans by local authorities. These plans introduce the principle of optimised sectorial zoning with three priority levels that are aimed to facilitate the evacuation process and limit human losses in case of lahars that could severely impact and reduce the efficiency of evacuation strategies. One must take into account the territorial isolation risk in volcanic crisis 
response planning as well as in land planning. It is necessary indeed to reduce the number of exposed assets and their vulnerability by diversifying resources outside of the volcanic hazard area and improving their accessibility. In the West Indies, and more specifically in Guadeloupe, it is now time to get seriously prepared and without delay for a future volcanic crisis. In addition to designing efficient operational preventive evacuation strategies, crisis response planning must also consider strategies for efficient and socially acceptable, temporary or final, relocation of evacuated populations. It is crucial in all phases of volcanic emergency response to anticipate, in the short, medium and long term, the urgent needs in securing and providing drinking water for a large evacuated population as well as to address the vulnerability of water treatment and sewer facilities. These are crucial and fundamental issues will significantly challenge efficient and long-lasting strategies for responding to a future volcanic crisis on Guadeloupe and Martinique. It is worth recalling that a volcanic crisis can be sustained over a long period of time, such as the one which is still ongoing on the neighbouring island of Montserrat, and that started in 1995 (Sparks and Young 2002; Wadge et al., 2014). The upcoming update of the "volcano specific dispositions" of the ORSEC contingency plans in Guadeloupe and Martinique constitute an important opportunity to integrate the vast corpus of new knowledge on volcanic phenomena and risk management into efficient and operational volcanic crisis response strategies. This objective is even more timely given the context of the current multiparameter unrest at La Soufrière of Guadeloupe that reached its highest level for seismicity in the last 42 years since the end of the 1976-1977 eruption and has forced new restrictions of access to the summit of the volcano and state of reinforced vigilance by the "Institut de physique du globe de Paris" and the Volcanological and seismological Observatory of Guadeloupe (OVSGIPGP) (Moretti et al. in review; OVSG-IPGP 2009-2019).

\begin{abstract}
Abbreviations
BD TOPO: Base de Données TOPOgraphique / TOPOgraphic Database (http:// professionnels.ign.fr/bdtopo); BRGM : Bureau de Recherches Géologiques et Minières / Geological and Mining Research Service (https://www.brgm.fr/); IGN: Institut national de l'information Géographique et forestière / National Institute for Geographical and Forestry Information (http://www.ign.fr/); INSEE: Institut national de la statistique et des études économiques / National Institute for Statistics and Economic Studies (https://insee.fr/fr/accueil); IPGP: Institut de Physique du Globe de Paris / Institute of Earth Physics of Paris (http://www.ipgp.fr/fr); ORSEC: Organisation de la Réponse de SEcurité Civile / Organisation of the Civil Defense Response; OSM: Open Street Map project (https://www.openstreetmap.org); PPRn: Plan de Prévention des Risques naturels / Natural Risk Prevention Plan; PSS: Plan de Secours Spécialisé
\end{abstract} / Specialized Emergency Plan; RD: Route Départementale / Departmental Road

\section{Acknowledgements}

The authors would like to thank the management and personnel of the Observatoire Volcanologique et Sismologique de Guadeloupe (OVSG-IPGP) and the Observatoire Volcanologique et Sismologique de Martinique (OVSM-IPGP), the Office of Roads in Guadeloupe, the Service interministériel de défense et protection civile (SIDPC) from the Préfecture in Guadeloupe and in Martinique, the Etat-Major Interministériel de Zone Antilles (EMIZA) in Martinique for their collaboration and logistical support. Data was obtained from the IGN and INSEE. Our thanks also go out to the Editor and two reviewers of this article.

\section{Authors' contributions}

All authors contributed equally sharetime to this work. All authors read and approved the final manuscript.

\section{Authors' information}

Frédéric Leone, Professor, Geographer in disaster studies and natural risk management, Université Paul Valéry Montpellier 3, France

Jean-Christophe Komorowski, Professor, Volcanologist, Scientist-in-charge of French volcanological and seismological observatories, Université de Paris, Institut de physique du globe de Paris, CNRS, France

Monique Gherardi-Leone, Engineer, Geographer, spatial analyses and GIS, Université Paul Valéry Montpellier 3, France

Guillaume Lalubie, PhD, Geographer, lahars studies, Université des Antilles, France

\section{Funding}

This work was supported by EU Project EXPLORIS (EVR1-2001-00047), by the Institut National des Sciences de I'Univers (INSU-CNRS), the Service National d'observation en volcanologie (SNOV, CNRS-INSU) and the CASAVA Project, 2009-2015 (ANR-09-RISK-02, coordinator J.C. Komorowski).

\section{Availability of data and materials}

All supporting GIS data are available upon request to Professor Frédéric Leone.

Ethics approval and consent to participate

No ethical approval nor consent to participate was required for this study.

Consent for publication

All the authors and the collaborators who provided the supporting data give their consent for publication.

\section{Competing interests}

The authors declare that they have no competing interests.

\section{Author details}

'Université Paul Valéry Montpellier 3, site de St Charles, Route de Mende, 34199 Montpellier Cedex 5, France. ${ }^{2}$ Institut de physique du globe de Paris, Université de Paris, CNRS, Paris, France. ${ }^{3}$ Université des Antilles, Martinique, France.

Received: 23 May 2019 Accepted: 5 November 2019

Published online: 19 December 2019

\section{References}

Alberico I, Petrosino P, Maglione G, Bruno L, Capaldo FS, Dal PA, Lirer L, Mazzola $S$ (2012) Mapping the vulnerability for evacuation of the Campi Flegrei territorial system in case of a volcanic unrest. Nat Hazards 64:1823-1854

André G (2004) Cartographie du risque naturel dans le monde. Etude comparative entre Une approche d'ordre social et Une approche d'ordre économique de la vulnérabilité. Cybergeo: Eur J Geo[En ligne], Environnement, Nature, Paysage, document 286, http://cybergeo.revues. org/2614. https://doi.org/10.4000/cybergeo.2614

Appert M, Chapelon L (2008) La vulnérabilité des réseaux routiers urbains face aux risques d'altération. In: Leone $F$, Vinet $F$ (eds) La mise en carte des risques naturels. Diversité des approches, Géorisques, no. 2, Ed. Presses Universitaires de la Méditerranée, Montpellier, pp 47-58

Aubaud C, Athanase J-E, Clouard V, Barras A-V, Sedan O (2013) A review of historical lahars, floods, and landslides in the Prêcheur river catchment (Montagne Pelée volcano, Martinique island, Lesser Antilles). Bulletin Société Géologique de France 184(1-2):137-154

Bavoux JJ, Chapelon L (2014) In: Colin A (ed) "Dictionnaire d'analyse spatiale", Paris

Baxter P, Neri A, Todesco M (1998) Physical modelling and human survival in pyroclastic flows. Nat Hazards 17:163-176

BD TOPO, 2009. Base de Données TOPOgraphique / TOPOgraphic Database. http://professionnels.ign.fr/bdtopo. 
Bono F, Gutiérrez E (2011) A network-based analysis of the impact of structural damage on urban accessibility following a disaster: the case of the seismically damaged port au prince and Carrefour urban road networks. J Transp Geogr 19(6):1443-1455

Boudon G, Komorowski J-C, Villemant B, Semet MP (2008) A new scenario for the last magmatic eruption of La Soufriere of Guadeloupe (Lesser Antilles) in 1530 AD evidence from stratigraphy radiocarbon dating and magmatic evolution of erupted products. J Volcanol Geotherm Res 178(3):474-490

Boudon G, Le Friant A, Komorowski J-C, Deplus C, Semet MP (2007) Volcano flank instability in the Lesser Antilles arc: diversity of scale, processes, and temporal recurrence. J Geophys Res 112(B8):B08205

Boudon G, Le Friant A, Villemant B, Viode J-P (2005) Martinique. In: Lindsay JM, Robertson REA, Shepherd JB, Ali S (eds) Volcanic hazard atlas of the Lesser Antilles, seismic research unit. The University of the West Indies, Trinidad, pp 127-146

Brown S, Loughlin S, Sparks S, Vye-Brown C, Barclay J, Calder E, Cottrell E, Jolly G, Komorowski J-C, Mandeville C, Newhall C, Palma J, Potter S, Valentine G (2015a) Global volcanic hazard and risk. In: Loughlin S, Sparks S, Brown S, Jenkins S, Vye-Brown C (eds) Global volcanic hazards and risk. Cambridge University Press, CambridgeISBN: 9781316276273, http://ebooks.cambridge. org/ebook.jsf?bid=CBO9781316276273, pp 81-172

Brown SK et al (2015b) Global distribution of volcanism: regional and country profiles. In: Report IV of the GVM/AVCEI contribution to the UN-ISDR global assessment of risks 2015 (GAR 15), A report by the Global Volcano Model and the International Association of Volcanology and Chemistry of the Earth's Interior, p 797

Carver S, Quincey D (2016) A conceptual framework of volcanic evacuation simulation of Merapi using agent-based model and GIS. Procedia Soc Behav Sci 227:402-409

CASAVA (2009-2015) Understanding and assessing volcanic hazards, scenarios, and risks in the Lesser Antilles: implications for decision-making, crisis management, and pragmatic development. ANR-RISK-09-002 project, France (coordinator J-C Komorowski); https://sites.google.com/site/casavaanr/home; last Accessed on 27 Oct 2019

CGDD (Commissariat Général au Développement Durable / Service de l'observation et des statistiques) (2012) Méthodes d'estimation de population et de logements en zone inondable Document de travail $n^{\circ} 8 \mathrm{p}$, https:// www.epsilon.insee.fr/jspui/bitstream/1/84866/2/20513.pdf

Chang SE (2003) Transportation planning for disasters: an accessibility approach Environ Plan A 35(6):1051-1072

Chenet M, Grancher D, Redon M (2014) Main issues of an evacuation in case of volcanic crisis: social stakes in Guadeloupe (Lesser Antilles arc). Nat Hazards 73(3):2127-2147. https://doi.org/10.1007/s11069-014-1184-6

D'Ercole R, Hardy S, Metzger P, Robert J, Gluski P (2012) Les dimensions spatiales et territoriales de la gestion de crise à Lima. VertigO - la revue électronique en sciences de l'environnement 12 Numéro, http://vertigo.revues.org/12009. https://doi.org/10.4000/vertigo.12009

D’Ercole R, Metzger P (2009) La vulnérabilité territoriale: Une nouvelle approche des risques en milieu urbain. Cybergeo: Eur J Geohttp://cybergeo.revues. org/22022. https://doi.org/10.4000/cybergeo.22022

Dauphiné A, Provitolo D (2007) La résilience: un concept pour la gestion des risques. Annales de géographie 2:115-125

De Bélizal E (2013) Les impacts des lahars du volcan Merapi (Java, Indonésie) après l'éruption de 2010. Géomorphologie: Relief, Processus, Environ 19(4). http://geomorphologie.revues.org/10406). https://doi.org/10.4000/ geomorphologie.10406

De Bélizal E, Lavigne F, Hadmoko DS, Degeai JP, Dipayana GA, Mutaqin BW et al (2013) Rain-triggered lahars following the 2010 eruption of Merapi volcano, Indonesia : a major risk. J Volcanol Geotherm Res 261:330-347

Defossez S., Vinet F., Leone F., 2017, "Assessing vulnerability to flooding: Progress and limitations", in: Vinet F. (eds.): Floods, volume 1 - risk knowledge, ISTE Press \& Elsevier, 241-257, https://doi.org/10.1016/B978-1-78548-268-7.50014-6

Demoraes F (2009) De l'intérêt d'une étude Sur la vulnérabilité des réseaux routiers et de transport pour la compréhension des vulnérabilités territoriales. Le cas du District Métropolitain de Quito (Équateur). Cybergeo: Eur J Geohttp://cybergeo.revues.org/22101. https://doi.org/10.4000/cybergeo.22101

D'Ercole R, Rançon JP (1994) La future éruption de la Montagne Pelée: risque et representations. Mappemonde 4:31-36

Dijkstra EW (1959) A note on two problems in connexion with graphs. Numer Math 1:269-271. https://doi.org/10.1007/bf01386390

ERCC (Emergency Response Coordination Centre), 2017, "DG ECHO Daily map, 27/11/2017, Indonesia, Agung Volcano Eruption", https://erccportal.jrc.ec. europa.eu/getdailymap/docld/2317
Feuillard M (2011) La Soufrière de la Guadeloupe, un volcan et un peuple. Jasor, Pointe-à-Pitre

Feuillard M, Allegre C, Brandeis G, Gaulon R, Le Mouel JL, Mercier J, Pozzi J, Semet MP (1983) The 1975-1977 crisis of La Soufrière de Guadeloupe (F.W.I): a still-born magmatic éruption. J Volcanol Geotherm Res 16:317-334

Florczyk AJ, Corbane C, Ehrlich D, Freire S, Kemper T, Maffenini L, Melchiorri M, Pesaresi M, Politis P, Schiavina M, Sabo F, Zanchetta L (2019) GHSL data package 2019. EUR 29788 EN, Publications Office of the European Union, LuxembourgISBN 978-92-76-08725-0, , JRC 117104. https://doi.org/10.2760/ 062975

Galland JP (2010) Critique de la notion d'infrastructure critique. Flux 81(3):6-18

Girres JF, Leone F, Péroche M, Gustave G, Gherardi M (2018) Analysis of tsunami evacuation maps for a consensual symbolization rules proposal. Int J Cartograp. https://doi.org/10.1080/23729333.2018.1440711

Gleyze (2005) La vulnérabilité structurelle des réseaux de transport dans un contexte de risques Thèse de doctorat, Université Paris 7, Laboratoire COGIT-IGN

GPV (Global Volcanism Program) (2013). Venzke E (ed) Volcanoes of the world database, vol 4.8.3. Smithsonian Institution Downloaded 11 Oct 2019. https:// volcano.si.edu/list volcano holocene.cfm

Handford D, Rogers A (2012) An agent-based social forces model for driver evacuation behaviours. Prog Artificial Intell 1(2):173-181

Hincks TK, Komorowski J-C, Sparks RSJ, Aspinall W (2014) Retrospective analysis of uncertain eruption precursors at La Soufrière volcano, Guadeloupe, 1975-77: volcanic hazard assessment using a Bayesian belief network approach. J Appl Volcanol 3:1-26

IFRCa (International Federation of Red Cross and Red Crescent Societies) (2019) Emergency plan of action final report Vanuatu: Ambae volcanic eruption 2018 Report MDRVU006, https://reliefweb.int/sites/reliefweb.int/files/resources/ MDRVU006n2.pdf

IFRCb (International Federation of Red Cross and Red Crescent Societies) (2019) 12-month update Guatemala: volcanic eruption (Fuego volcano) 08 October 2019, Report MDRGT013, https://reliefweb.int/sites/reliefweb.int/files/ resources/MDRGT01312m.pdf

Jumadi CS, Quincey D (2016) A conceptual framework of volcanic evacuation simulation of Merapi using agent-based model and GIS. Procedia Soc Behav Sci 227:402-409

Kennan G (1902) "The tragedy of Pelée, a narrative of personal experience and observation in Martinique", 1969. Negro Universities Press, New York

Komorowski JC, Boudon G, Semet MP, Beauducel F, Anténor-Habazac C, Bazin S, Hammouya G (2005) Guadeloupe. In: Lindsay JM, Robertson REA, Shepherd JB, Ali S (eds) Volcanic hazard atlas of the Lesser Antilles, Seismic research unit. The University of the West Indies, Trinidad, pp 67-105

Komorowski JC, Legendre Y, Caron B, Boudon G (2008) Reconstruction and analysis of sub-plinian tephra dispersal during the 1530 AD Soufrière (Guadeloupe) eruption: implications for scenario definition and hazards assessment. J Volcanol Geotherm Res 178(3):491-515

Komorowski J-C, Morin J, Jenkins S, Kelman I (2016) Challenges of volcanic crises on small islands states. In: Bird D, Fearnley C, Haynes K, Jolly G, McGuire B (eds) Observing the Volcano World: Volcano Crisis Communication, advances in volcanology. IAVCEl, Springer Verlag. https://doi.org/10.1007/11157_2015_15

Lacroix A (1904) La Montagne Pelée et ses éruptions. Editions Masson et Cie, Paris

Lalubie G (2011) Les lahars historiques aux Antilles françaises: inventaire des sources documentaires et analyse de l'activité hydro-volcanogéomorphologique. Rapport d'étude. Université Antilles-Guyane Rapport GRED/AIHP-GEODE, Projet ANR Casava, IPGP. 76 p.

Lalubie G (2013) Les lahars et les laves torrentielles historiques aux Antilles françaises: un risque hydro-volcano-géomorphologique majeur. Phys-Géo Géograph Phys Environ 7:83-109

Lämmel G, Grether D, Nagel K (2010) The representation and implementation of time-dependent inundation in large-scale microscopic evacuation simulations. Transport Res Part C: Emerg Technol 18(1):84-98

Lavigne F, Thouret JC (2000) Les lahars: dépôts, origines et dynamique. Bulletin de la Société Géologique de France 171(5):545-557

Lavigne F, Thouret J-C, Voight B, Suwa H, Sumaryono A (2000) Lahars at Merapi volcano: an overview. J Volcanol Geotherm Res 100:423-456

Legendre Y (2012) Reconstruction fine de l'histoire éruptive et scénarii éruptifs à La Soufrière de Guadeloupe: vers un modèle intégré de fonctionnement du volcan. Institut de Physique du Globe de Paris et Université Paris Diderot, Paris Thèse de Doctorat, Vol. 1: 1-430; Vol. 2, Annexes: 1-257

Leone F, Colas A, Garcin Y, Eckert N, Jomelli V, Gherardi M (2014a) The snow avalanches risk on alpine roads network. Assessment of impacts and 
mapping of accessibility loss. J Alpine Res/ Revue de géographie alpine. https://doi.org/10.4000/rga.2491

Leone F, De Richemond N, Vinet F (2010) Aléas naturels et gestion des risques. PUF, Collection Licence Géographie, Paris

Leone F, Deymier J, Chapelon L, Colas A, Jomelli V (2011) Risques naturels et accessibilité territoriale : le cas des debris flows dans les Alpes. In: Actes du Colloque international du GIS Collège international des sciences du Territoire. Fonder les sciences du territoire, Paris, pp 290-296

Leone F, Gaillard JC (1999) Analysis of the institutional and social responses to the eruption and the lahars of mount Pinatubo volcano from 1991 to 1998 (Central Luzon, Philippines). Geojournal 49:223-238

Leone F, Lesales T (2009) The interest of cartography for a better perception and management of volcanic risk: from scientific to social representations. J Volcanol Geotherm Res 186:186-194. https://doi.org/10.1016/j.jvolgeores. 2008.12.020

Leone F, Péroche M, Gutton R (2014b) Le risque tsunami en Martinique: planifier Une évacuation préventive en optimisant l'accessibilité de sites refuges. VertigO - la revue électronique en sciences de l'environnement 14:2http:// vertigo.revues.org/15046. https://doi.org/10.4000/vertigo.15046

Leone F, Péroche M, Lagahé E, Gherardi M, Sahal A, Vinet F, Hachim S, Lavigne F (2013) Territorial accessibility modeling for tsunami crisis Management in FrenchAdministered Mayotte (Indian Ocean). Annales de géographie 693:502-524

Lepointe E (1984) Essai sur la réponse sociale à une catastrophe : La Soufrière de Guadeloupe en 1976, Thèse de doctorat, Université de Paris X Nanterre, 975 p.

Lesales T (1999) Zone d'abri et zone à risque: deux notions clés dans la gestion des crises volcaniques dans les petites Antilles. Le cas de La Soufrière Hills (Montserrat) et de la Montagne Pelée (Martinique). In: Pagney F, Leone F (eds) Les Antilles, terres à risques. Terres d'Amériques, No. 2, Ed. Karthala, Paris, pp 134-145

Lesales T (2005) La vulnérabilité des sociétés exposées aux risques volcaniques, le cas des petites Antilles. Thèse de doctorat. Géographie, Université des Antilles et de la Guyane, 378 p. http://www.theses.fr/2005AGUY0590

Lesales T, Leone F (2011) L'intégration du risque volcanique dans un PPRn multirisques: principes et limites de l'approche en Martinique. Revue Géologues 169:82-86

Lindsay JM, Robertson REA, Shepherd JB, Ali S (eds) (2005) "Volcanic hazard atlas of the Lesser Antilles", seismic research unit. The University of the West Indies, Trinidad

Liu Y, Okada N, Shen D, Kajitani Y (2010) Development of flood exposure map considering dynamics of urban life. Ann Dis Prev Res Inst 53(B). 12 p. http:// www.dpri.kyoto-u.ac.jp/nenpo/no53/ronbunB/a53b0p17.pdf

Loughlin SC, Baxter PJ, Aspinall WP, Darroux B, Harford CL, Miller AD (2002) Eyewitness accounts of the 25 June 1997 pyroclastic flows and surges at Soufrire Hills volcano, Montserrat, and implications for disaster management. In: Druitt TH, Kokelaar BP (eds) The eruption of Soufrière Hills volcano, Montserrat, from 1995 to 1999, vol 21. Geological Society, LondonMemoirs, pp 211-230

Mas M (2012) Analyse comparative des représentations du risque volcanique en milieu insulaire (Guadeloupe, Martinique et Réunion)Thèse de doctorat, vol 3. Géographie, Université Paul Valéry Montpellier, 479 p. https://tel.archivesouvertes.fr/file/index/docid/981943/filename/2012_mas_arch.pdf

Mei ETW (2013) Gestion des évacuations lors des crises volcaniques. Etudes de cas du volcan Merapi, Java, IndonésieThèse de doctorat, Géographie. Université Paris 1 Panthéon-Sorbonne, 333 p. https://tel.archives-ouvertes.fr/ tel-01001681/file/2013-07_-_MEl_-_Ges.pdf

Mei ETW, Lavigne F, Picquout A, De Bélizal E, Brunstein D, Grancher D, Sartohadi J, Cholik N, Vidal C (2013) Lessons learned from the 2010 evacuations at Merapi volcano. J Volcanol Geotherm Res. https://doi.org/10.1016/j. jvolgeores.2013.03.010

Moretti R, Komorowski J-C, Ucciani G, Burtin A, Moune S, Robert V, Bonifacie M, Jessop D, Deroussi S, de Chabalier J-B, Beauducel F, Gibert D, Didier T, Kitou K, Vallée M, Feuillet N, Tamburello G, Shreve T, Saurel J-M, Lemarchand A, Rosas-Carbajal M, Allard P, Agrinier P, Le Friant A, Chaussidon M (accepted) The 2018 unrest phase at La Soufrière of Guadeloupe (French West Indies) andesitic volcano: scrutiny of a failed but prodromal phreatic eruption. J Volcanol Geotherm Res minor revisions requested. $12 \mathrm{p}$.

Morin J (2012) Gestion institutionnelle et réponses des populations face aux crises volcaniques: études de cas à La Réunion et en Grande Comore. Thèse de doctorat. Université de la Réunion, p 472 https://hal.univ-reunion.fr/tel$01199868 \mathrm{v} 1$
Nabaa M (2011) Morphodynamique de réseaux viaires. Application au risqué. Thèse de doctorat. Université du Havre, France, p 256 https://pdfs. semanticscholar.org/e218/4fb82c86b96789682dc27b8ac45d04197a7e.pdf

Newhall CG, Punongbayan RS (1996) Fire and mud: eruption and lahars of Mt Pinatubo, Philippines. University of Washington Press / Philippine Institute of Volcanology and Seismology, Seattle, Quezon City, p 1126

November V (2012) Rester connecté à tout prix? Vulnérabilité des infrastructures critiques et gestion de crise. Geographica Helvetica 66(2):84-91

OVSG-IPGP (1999-2019) Monthly report on the volcanic activity of La Soufrière de Guadeloupe and on the regional seismicity. Observatoire Volcanologique et Sismologique de la Guadeloupe, Institut de physique du globe de Paris, IPGP-CNRS-INSU, Conseil Général de Guadeloupe Published online at: http:// www.ipgp.fr/fr/ovsg/bulletins-mensuels-de-lovsg; last Accessed 24 Oct 2019; ISSN 1622-4523

OVSG-IPGP (2009-2019) Bilan trimestriel de l'activité volcanique de La Montagne Pelée et de la sismicité régionale de Martinique. Observatoire Volcanologique et Sismologique de Martinique, Institut de physique du globe de Paris, IPGP-CNRS-INSU, Collectivité Territoriale de Martinique Published online at: http://www.ipgp.fr/fr/ovsm/bilans-trimestriels-de-lovsm; last Accessed 27 Oct 2019; ISSN 2105-2301

OVSM-IPGP (2018) Les lahars de la rivière du Prêcheur. Evolution et suivi des phénomènes de glissements et de lahars depuis janvier 2018. Observatoire Volcanologique et Sismologique de la Martinique, Institut de physique du globe de Paris, IPGP-CNRS-INSU Published online at: http: //www.ipgp.fr/fr/ ovsm/lahars-de-riviere-precheur; last Accessed 27 Oct 2019

Pagneux E (2015a) Öræfajökull: evacuation time modelling of areas prone to volcanogenic floods. In: Pagneux E, Gudmundsson MT, Karlsdóttir S, Roberts MJ, Pagneux E, Gudmundsson MT, Karlsdóttir S, Roberts MJ (eds) Volcanogenic floods in Iceland: an assessment of hazards and risks at Öræfajökull and on the Markarfljót outwash plain. IMO, IES-UI, NCIP-DCPEM, Reykjavík, pp 141-164

Pagneux E (2015b) Öræfi district and Markarfljót outwash plain: Spatio-temporal patterns in population exposure to volcanogenic floods. In: Pagneux E, Gudmundsson MT, Karlsdóttir S, Roberts MJ, Pagneux E, Gudmundsson MT, Karlsdóttir S, Roberts MJ (eds) Volcanogenic floods in Iceland: an assessment of hazards and risks at Öræfajökull and on the Markarfljót outwash plain. IMO, IES-UI, NCIP-DCPEM, Reykjavík, pp 125-142

Péroche M, Leone F, Gutton R (2014) An accessibility graph-based model to optimize tsunami evacuation sites and routes in Martinique, France. Adv Geosci 38:1-8. https://doi.org/10.5194/adgeo-38-1-2014

Peruzzetto M, Komorowski J-C, Le Friant A, Rosas-Carbajal M, Mangeney A, Legendre $Y$ (2019) Modeling of partial dome collapse of La Soufrière of Guadeloupe volcano: implications for hazard assessment and monitoring. Sci Rep 9:13105. https://doi.org/10.1038/s41598-019-49507-0

Pierson TC, Janda RJ, Thouret J-C, Borrero CA (1990) Perturbation and melting of snow and ice by the 13 November 1985 eruption of Nevado del Ruiz, Colombia, and consequent mobilization, flow and deposition of lahar. J Volcanol Geotherm Res 41:17-66

Postance B, Hillier J, Dijkstra T, Dixon N (2017) Extending natural hazard impacts: an assessment of landslide disruptions on a national road transportation network. Environ Res Lett 12(1):014010

Préfecture de la Région Guadeloupe (1999) Volcan de la Soufrière. Plan de Secours Spécialisé, Basse-Terre, p 98

Préfecture de la Région Guadeloupe (2019) Dispositions spécifiques ORSEC Guadeloupe: phénomènes volcaniques Published on line on 20-01-2019. http://www.quadeloupe.gouv.fr/Politiques-publiques/Risques-naturelstechnologiques-et-sanitaires/Activite-volcanique-de-la-Soufriere-de-Guadeloupeet-sismicite-regionale/Le-plan-ORSEC-Volcan\#; last Accessed 26 Oct 2019

Préfecture de la Région Martinique (2002) Plan de Secours Spécialisé. Eruption volcanique. Montagne Pelée, Fort-de-France, p 119

Reghezza-Zitt M, Rufat S, Djament-Tran G, Le Blanc A, Lhomme S (2012) What resilience is not : uses and abuses. Cybergeo: Eur J Geo http://cybergeo. revues.org/25554. https://doi.org/10.4000/cybergeo.25554

Sahal A, Leone F, Péroche M (2013) Complementary methods to plan pedestrian evacuation of the French Riviera's beaches in case of tsunami threat: graphand multi-agent-based modelling. Nat Hazards Earth Syst Sci 13:1735-1743. https://doi.org/10.5194/nhess-13-1735-2013

Sedano S (2013) Evolution de l'urbanisation en zones volcaniques: étude comparative entre la Guadeloupe et la Martinique (petites Antilles) Mémoire de master 1 GCRN (dir. F. Leone), Projet ANR CASAVA, Université Paul Valéry Montpellier 3

Siebert L, Simkin T, Kimberly P (2010) Volcanoes of the world, 3rd edn. University of California Press, Berkeley, p 568 
Sohn J (2006) Evaluating the significance of highway network links under the flood damage: an accessibility approach. Transp Res A Policy Pract 40(6):491-506

Sparks RSJ, Barclay J, Calder ES, Herd RA, Komorowski J-C, Norton GE, Ritchie L, Voight B, Woods AW (2002) Generation of a debris avalanche and violent pyroclastic density current: the boxing day eruption of 26 December 1997 at the Soufrière Hills volcano, Montserrat. In: Druitt TH, Kokelaar BP (eds) The eruption of Soufrière Hills volcano, Montserrat, from 1995 to 1999, vol 21. Geological Society, LondonMemoirs, pp 409-434

Sparks RSJ, Young SR (2002) The eruption of Soufrière Hills volcano, Montserrat (1995-1999): overview of scientific results. In: Druitt TH, Kokelaar BP (eds) The eruption of Soufrière Hills volcano, Montserrat, from 1995 to 1999, vol 21. Geological Society, LondonMemoirs, pp 45-69

Stieltjes L, Mirgon C (1998) Approche méthodologique de la vulnérabilité aux phénomènes volcaniques. Test d'application Sur les réseaux de la MartiniqueRapport de synthèse, BRGM, R, vol 40098

Thouret J-C (1990) Effects of the November 13, 1985 eruption on the snow pack and ice cap of Nevado del Ruiz volcano, Colombia. J Volcanol Geotherm Res 41:177-201

Ukai T (1997) The great Hanshin-Awaji earthquake and the problems with emergency medical care. Ren Fail 19(5):633-645

Ursulet L (1997) Le désastre de 1902 à la Martinique. L'éruption de la Montagne Pelée et ses consequences. L'Harmattan, Paris

Utasse M, Jomelli V, Grancher D, Leone F, Brunstein D, Virmoux C (2016) Territorial accessibility and decision-making structure related to debris flow impacts on roads in the French Alps. Int J Disas Risk Sci:1-12. https://doi.org/ 10.1007/s13753-016-0088-3

Villemant B, Hammouya G, Michel A, Semet M, Komorowski J-C, Boudon G, Cheminée J-L (2005) The memory of volcanic waters: shallow magma degassing revealed by halogen monitoring in thermal springs of La Soufrière volcano (Guadeloupe, Lesser Antilles). Earth Planet Sci Lett 237:710-728

Villemant B., Komorowski J.-C., Dessert C., Michel A., Crispi O., Hammouya G., Beauducel F., De Chabalier, 2014. Evidence for a new shallow magma intrusion at La Soufrière of Guadeloupe (Lesser Antilles). Insights from longterm geochemical monitoring of halogen-rich hydrothermal fluids. Jour. Volcanol. Geotherm. Res., 285, 247-2770. https://doi.org/10.1016/j.jvolgeores. 2014.08.002.

Voight B., 1990. The 1985 Nevado del Ruiz volcano catastrophe: anatomy and retrospection. Journal of Volcanology and Geothermal Research, 44, 349-386.

Wadge G., Voight B., Sparks R.S.J. Cole, P.D. Loughlin S.C., Robertson R.E.A., 2014 Chapter 1: An overview of the eruption of Soufrière Hills Volcano, Montserrat from 2000 to 2010. In: Wadge, G., Robertson, R. E. A. \& Voight, B. (eds), The Eruption of Soufrière Hills Volcano, Montserrat from 2000 to 2010. Geological Society, London, Memoirs, 39, 71-92. doi: 10.1144/M39.1, 1-40.

Wilkinson E., 2015. Beyond the volcanic crisis: co-governance of risk in Montserrat. Journal of Applied Volcanology, 4(1), 3.

Wilson T., Cole J., Johnston D., Cronin S., Stewart C., Dantas A., 2012. Short-and long-term evacuation of people and livestock during a volcanic crisis: lessons from the 1991 eruption of Volcán Hudson, Chile. Journal of Applied Volcanology, 1:2, 1-11.

Wood N, Soulard C (2009) Variations in population exposure and sensitivity to lahar hazards from Mount Rainier, Washington. J Volcanol Geotherm Res 188(4):367-378

Zaninetti J.M., 2013. Adaptation urbaine post-catastrophe : la recomposition territoriale de La Nouvelle Orléans. Cybergeo : European Journal of Geography, Space, Society, Territory, document 636. http://cybergeo.revues. org/25805.

\section{Publisher's Note}

Springer Nature remains neutral with regard to jurisdictional claims in published maps and institutional affiliations.

Ready to submit your research? Choose BMC and benefit from:

- fast, convenient online submission

- thorough peer review by experienced researchers in your field

- rapid publication on acceptance

- support for research data, including large and complex data types

- gold Open Access which fosters wider collaboration and increased citations

- maximum visibility for your research: over $100 \mathrm{M}$ website views per year

At $\mathrm{BMC}$, research is always in progress.

Learn more biomedcentral.com/submissions 